\title{
Microstructure and phase stability of single crystal NiAl alloyed with $\mathrm{Hf}$ and $\mathrm{Zr}$
}

\author{
I. E. Locci \\ Case Western Reserve University, Cleveland, Ohio 44106, and NASA Lewis Research Center, \\ Cleveland, Ohio 44135
}

R. M. Dickerson

NYMA, Inc., Cleveland, Ohio 44I24

A. Garg, R. D. Noebe, J. D. Whittenberger, and M. V. Nathal

NASA Lewis Research Center, Cleveland, Ohio 44135

\author{
R. Darolia \\ General Electric Aircraft Engines, Cincinnati, Ohio 45215
}

(Received 26 January 1996; accepted 24 July 1996)

Six near stoichiometric, NiAl single-crystal alloys, with $0.05-1.5$ at. \% of $\mathrm{Hf}$ and $\mathrm{Zr}$ additions plus $\mathrm{Si}$ impurities, were microstructurally analyzed in the as-cast, homogenized, and aged conditions. Hafnium-rich interdendritic regions, containing the Heusler phase $\left(\mathrm{Ni}_{2} \mathrm{AlH}\right)$, were found in all the as-cast alloys containing $\mathrm{Hf}$. Homogenization heat treatments partially reduced these interdendritic segregated regions. Transmission electron microscopy (TEM) observations of the as-cast and homogenized microstructures revealed the presence of a high density of fine $\mathrm{Hf}$ (or $\mathrm{Zr}$ ) and Si-rich precipitates. These were identified as G-phase, $\mathrm{Ni}_{16} \mathrm{X}_{6} \mathrm{Si}_{7}$, or as an orthorhombic NiXSi phase, where $\mathrm{X}$ is $\mathrm{Hf}$ or Zr. Under these conditions the expected Heusler phase $\left(\beta^{\prime}\right)$ was almost completely absent. The Si responsible for the formation of the $\mathrm{G}$ and NiHfSi phases is the result of molten metal reacting with the $\mathrm{Si}$-containing crucible used during the casting process. Varying the cooling rates after homogenization resulted in the refinement or complete suppression of the $G$ and NiHfSi phases. In some of the alloys studied, long-term aging heat treatments resulted in the formation of Heusler precipitates, which were more stable at the aging temperature and coarsened at the expense of the G-phase. In other alloys, long-term aging resulted in the formation of the NiXSi phase. The stability of the Heusler or NiXSi phases can be traced to the reactive element $(\mathrm{Hf}$ or $\mathrm{Zr}$ ) to silicon ratio. If the ratio is high, then the Heusler phase appears stable after long time aging. If the ratio is low, then the $\mathrm{NiHfSi}$ phase appears to be the stable phase.

\section{INTRODUCTION}

$\mathrm{NiAl}$ alloys, regarded as potential candidates for high temperature applications, require improvement in room temperature ductility or toughness as well as high temperature creep resistance to compete with today's superalloys. $\mathrm{NiAl}$ is one of the few intermetallic alloys that possesses excellent oxidation resistance at both intermediate and high temperatures mainly due to the formation of a protective $\mathrm{Al}_{2} \mathrm{O}_{3}$ scale. ${ }^{1.2}$ While the isothermal oxidation resistance of $\mathrm{NiAl}$ is outstanding, the cyclic oxidation resistance of $\mathrm{NiAl}$ is equally impressive when trace additions of reactive elements are present. Ternary additions, especially from group IV and $\mathrm{V}$ refractory metal elements, have also been shown to provide significant strengthening at high temperatures. In particular, the effect of $\mathrm{Hf}$ additions on the high temperature mechanical properties of polycrystalline NiAl was suggested to be very important, ${ }^{3}$ although creep tests at slower strain rates indicated that a polycrystalline, fine-grained $\mathrm{Ni}-47 \mathrm{Al}-0.8 \mathrm{Hf}$ (at. \%) alloy was weaker than expected. ${ }^{4}$ Similar results have been obtained on $\mathrm{NiAl}-\mathrm{Zr}$ alloys where significant strengthening was observed at lower temperatures and higher strain rates, but with a much smaller advantage at high temperatures and low strain rate conditions. ${ }^{5}$ Because grain boundary sliding contributes significantly to the creep rate, it is envisioned that the observed weakness in the latter studies could be circumvented through the use of single crystals.

Directional solidification has been used to produce $\mathrm{NiAl}$ single crystals for use in aeroturbine engines, in much the same way as many commercial superalloys. ${ }^{6-8}$ Several difficult milestones, however, have to be met before single crystal $\mathrm{NiAl}$ alloys can reach commercial use in engines. A balance of properties, including ductility, toughness, and high temperature strength, as 
well as controlled processing, refined joining techniques, and precise machining of $\mathrm{NiAl}$ are required before this material will be widely accepted. The first challenge is to produce a single crystal NiAl alloy with a controlled chemistry. Several processing techniques, such as Bridgman, Czochralski, modified edge-defined filmfed growth, and the containerless float zone process are available to produce NiAI single crystals. ${ }^{9.10}$ However, the high melting point of $\mathrm{NiAl}$, close to $1912 \mathrm{~K}$ which is about $300 \mathrm{~K}$ higher than the temperature used to process superalloys, pushes the stability of ceramic molds to their limit when in contact with molten NiAl. ${ }^{11,12}$ Therefore, even when single crystal processing is successful, moldmetal reactions are serious issues.

Consequently, the current research focuses on the characterization of the phases present after directional solidification of $\mathrm{NiAl}-\mathrm{Zr} / \mathrm{Hf}$ alloys and their stability, which is expected to play an important role in the high temperature behavior of these $\mathrm{NiAl}$ single crystals. A follow-up publication will discuss the elevated temperature deformation properties of $\mathrm{Hf}$-modified, $\mathrm{NiAl}$ single-crystal alloys. Preliminary results were published previously. ${ }^{13-1.5}$

\section{EXPERIMENTAL PROCEDURE}

Single-crystal ingots from three alloy systems (Table I) were microstructurally characterized by optical microscopy, scanning electron microscopy (SEM), and transmission electron microscopy (TEM). The first system is represented by four $\mathrm{NiAl}-\mathrm{Hf}$ alloys containing $0.1,0.3,1.0$, or 1.5 atomic percent (at. \%) Hf (alloy descriptions in the text are nominal compositions). The second system consisted of a NiAl-0.05 at. \% $\mathrm{Zr}$ alloy, which is considered one of the best alloys for cyclic oxidation resistance. ${ }^{1,2}$ The third system consisted of a $\mathrm{NiAl}-\mathrm{Hf}-\mathrm{Zr}$ alloy containing 1.0 at. \% $\mathrm{Hf}$ and 0.2 at. \% Zr. Alloys from the first two systems were prepared by a modified Bridgman technique using alumina-silicate shell molds at GEAE (Evendale, $\mathrm{OH}$ ). For comparison purposes, the chemistry of a binary NiAl single crystal produced by the modified Bridgman technique is included in Table I. The alloy from the third system was prepared using a containerless float zone technique at the University of Tennessee (Knoxville. $\mathrm{TN})^{9}$ using a pre-cast NiAl alloy rod induction melted in an argon atmosphere.

Samples oriented along the $\langle 001\rangle$ direction were wire electric discharge machined (EDM) from the as-cast ingots and ground into $3 \mathrm{~mm}$ diameter rods suitable for heat treatments and TEM specimen preparation. The specimens were given a standard homogenization heat treatment consisting of a solution treatment at $1590 \mathrm{~K}$ for $50 \mathrm{~h}$ in argon atmosphere followed by furnace cooling at a rate of $10 \mathrm{~K} / \mathrm{min}$. To understand the effect of cooling rate on the precipitation of second phases, selected specimens were also air cooled or water quenched from the solution temperature. To determine the stability of the second phases, homogenized specimens were exposed to short and long time aging heat treatments at $1300 \mathrm{~K}$ and $1400 \mathrm{~K}$.

Prior to examination of the specimens by optical microscopy, the samples were etched using a solution of $75 \mathrm{ml} \mathrm{HF}, 150 \mathrm{ml} \mathrm{H} \mathrm{H}_{2} \mathrm{O}$, and $100 \mathrm{~g}$, of molybdic acid. TEM foils were prepared by double-jet electropolishing of mechanically ground disks using either one of two chemical solutions maintained at $273 \mathrm{~K}$ : (a) $70 \%$ ethanol, $14 \%$ distilled water, $10 \%$ butylcellosolve, and $6 \%$ perchloric acid at $30 \mathrm{~V}$ or (b) $10 \%$ perchloric acid in methanol at $20 \mathrm{~V}$. TEM examinations and energy dispersive $x$-ray spectroscopy (EDXS) were conducted in

TABLE I. Composition (in at. \%) of the as-cast single crystal alloys

\begin{tabular}{|c|c|c|c|c|c|c|c|c|}
\hline \multirow[b]{2}{*}{ System } & \multirow[b]{2}{*}{ Target composition } & \multicolumn{6}{|c|}{ Composition (at. \%) } & \multirow[b]{2}{*}{$O$ (WPPM) } \\
\hline & & $\mathrm{Al}$ & $\mathrm{Ni}$ & $\mathrm{Zr}$ & $\mathrm{Hf}$ & $\mathrm{Si}$ & $\mathrm{C}$ (WPPM) & \\
\hline Binary NiAl & $\mathrm{NiAl}{ }^{a}$ & 50.0 & 49.9 & $\cdots$ & $\cdots$ & 0.07 & 110 & 80 \\
\hline \multicolumn{9}{|l|}{ System I } \\
\hline $\mathrm{NiAl}-\mathrm{Hf}$ & $\begin{array}{l}\mathrm{NiAl}-1.5 \mathrm{Hf}^{\mathrm{a}} \\
\mathrm{NiAl}-1.0 \mathrm{Hf}^{\mathrm{a}} \text { (top) (average of } 3 \text { samples) } \\
\mathrm{NiAl}-1.0 \mathrm{Hf}^{\mathrm{a}} \text { (bottom) (average of } 3 \text { samples) } \\
\mathrm{NiAl}-0.3 \mathrm{Hf}^{\mathrm{a}} \\
\mathrm{NiAl}-0.1 \mathrm{Hf}\end{array}$ & $\begin{array}{l}48.3 \\
47.3 \\
47.7 \\
49.8 \\
47.8\end{array}$ & $\begin{array}{l}49.4 \\
51.0 \\
51.0 \\
49.7 \\
51.8\end{array}$ & $\begin{array}{c}0.02 \\
\cdots \\
\cdots \\
\cdots \\
\cdots\end{array}$ & $\begin{array}{l}1.96 \\
1.23 \\
1.01 \\
0.3 \\
0.12\end{array}$ & $\begin{array}{l}0.26 \\
0.47 \\
0.26 \\
0.17 \\
0.28\end{array}$ & $\begin{array}{l}36 \\
20 \\
34 \\
32 \\
46\end{array}$ & $\begin{array}{r}50 \\
120 \\
120 \\
190 \\
69\end{array}$ \\
\hline \multicolumn{9}{|l|}{ System II } \\
\hline $\begin{array}{l}\mathrm{NiAl}-\mathrm{Zr} \\
\text { System III } \\
\end{array}$ & $\mathrm{NiAl}-0.05 \mathrm{Zr}^{\mathrm{a}}$ & 49.9 & 49.9 & 0.05 & $\cdots$ & 0.15 & 130 & 90 \\
\hline $\mathrm{NiAl}-\mathrm{Hf}-\mathrm{Zr}$ & $\mathrm{NiAl}-1.0 \mathrm{Hf}-0.2 \mathrm{Zr}^{\mathrm{b}}$ & 46.5 & 52.2 & 0.2 & 0.9 & 0.16 & NA & NA \\
\hline
\end{tabular}

${ }^{a}$ Modified Bridgman technique (GEAE, Evendale, $\mathrm{OH}$ ).

${ }^{\mathrm{b}}$ Containerless technique from a pre-cast ingot (University of Tennessee, Knoxville, TN). 

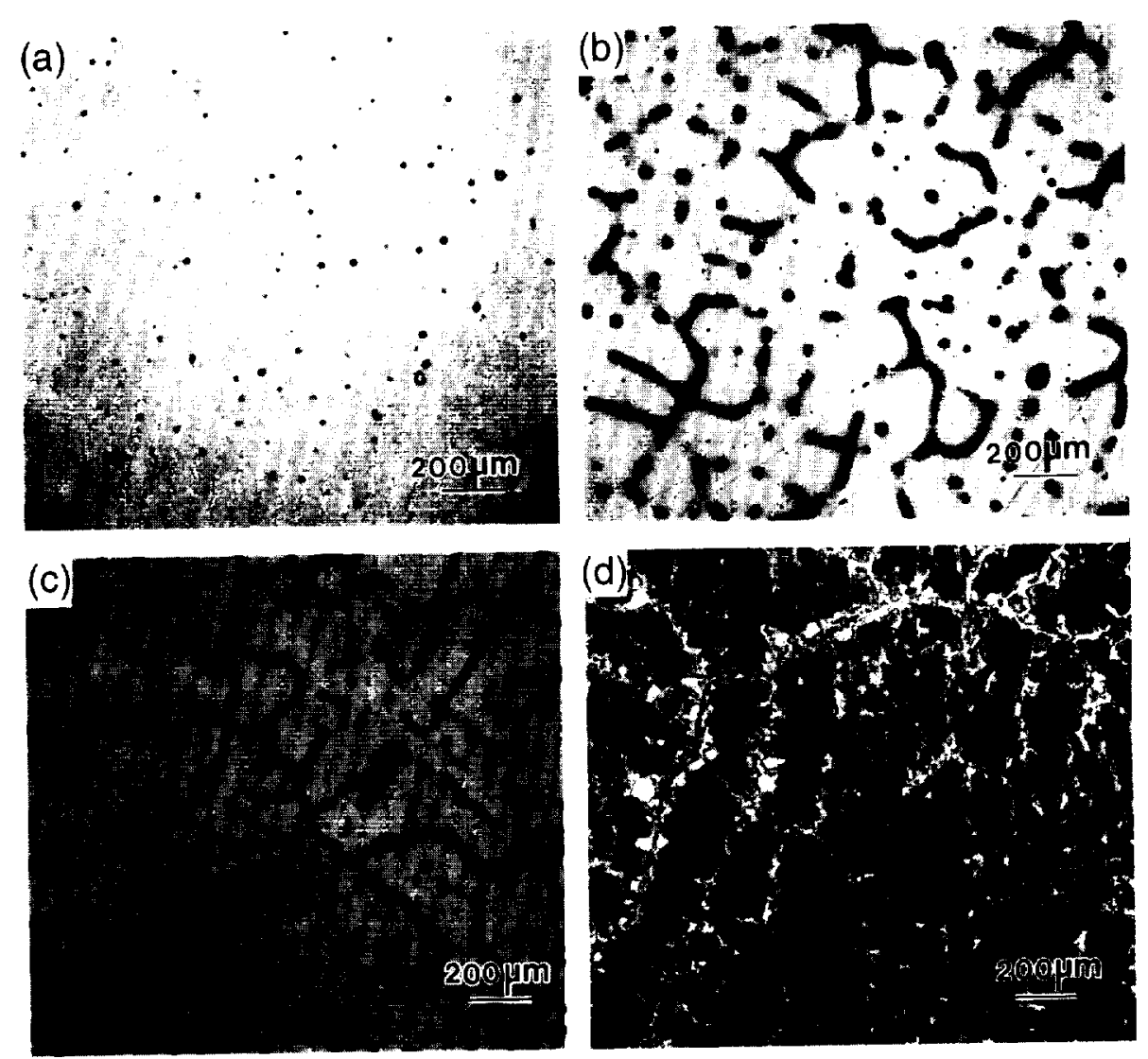

FIG. 1. Optical micrographs of the as-cast microstructures of NiAl single crystal alloys with various levels of Hafnium in atonic percent: (a) 0.1, (b) 0.3, (c) 1.0 , and (d) 1.5 .

a Philips EM400T microscope operating at $120 \mathrm{kV}$ and a KEVEX Si/Li $x$-ray detector. In some instances, etched TEM foils were used for SEM examination using a JEOL 840 scanning electron microscope to observe the second phase distribution. In addition, lattice parameters of the single-crystal NiAl matrix phase were determined by $\mathrm{x}$-ray diffraction. Vickers microhardness measurements were also conducted using a $50 \mathrm{~g}$ load and a $15 \mathrm{~s}$ dwell time; at least 10 microhardness measurements were taken for each condition.

\section{RESULTS}

\section{A. Chemical composition analysis}

Chemical composition analysis of these alloys revealed the unexpected presence of high levels of $\mathrm{Si}$ in all the alloys (Table I). Silicon contamination appears to come from the ceramic mold material used in the directional solidification process, since it was not present in the melt stock. These alumina-silicate mold materials are similar to those that have been used in the past to grow single crystal superalloys. However, due to the higher melting point ${ }^{16}(\sim 1950 \mathrm{~K})$ and casting temperatures of $\mathrm{NiAl}$ compared to superalloys, a more severe reaction between the molten metal and the mold is expected to occur. Furthermore, the presence of highly reactive elements $\mathrm{Hf}$ or $\mathrm{Zr}$, in the molten NiAl alloys, increased the degree of liquid-mold reaction, resulting in higher $\mathrm{Si}$ levels in those alloys compared to binary $\mathrm{NiAl}$. For example, the $\mathrm{Si}$ level (Table $\mathrm{I}$ ) in a binary $\mathrm{NiAl}$ single crystal produced under identical conditions, but with no Hf or $\mathrm{Zr}$ additions, is 3 to 7 times lower than that present in the alloys with ternary additions.

Concerns of compositional variations within a single crystal ingot prompted a chemistry assessment at various regions along the length of the ingots. An ingot of NiAl-1 at. \% Hf composition was used for this evaluation, and specimens from the top and bottom of the ingot were chemically analyzed. As indicated in Table I, a chemistry variation was observed along the length of the single crystal ingot. Samples labeled as top consistently had a higher level of $\mathrm{Hf}$ and $\mathrm{Si}$. An average chemical composition variation of $(\cong 0.2$ at. \% in $\mathrm{Hf}$ and $\mathrm{Si}$ contents was measured from top to bottom in this particular ingot.

In order to eliminate the Si contamination from the mold material during the single crystal growth process, a containerless floating zone process ${ }^{9}$ was explored. Unfortunately, this process requires a pre-cast ingot that was prepared by induction melting using a conventional 
mold that also contained $\mathrm{Si}$ as one of the mold additives. The resultant Si content in the system III alloy (Table I) turned out to be similar to that measured in alloys processed by the Bridgman melt processing technique. Moreover, the starting Hf stock material used in the initial processing of this system contained some $\mathrm{Zr}$ as an impurity, and thus $\mathrm{Zr}$ was also introduced in the alloy during the initial induction melting process.

\section{B. Microstructure of as-cast and homogenized alloys}

The microstructures of three NiAl single crystal alloy systems were studied in order to understand the effect of ternary additions on $\mathrm{NiAl}$ single crystals after exposure at high temperatures. Detailed study was conducted on the alloys containing Hf alone (system I); although, as described in this section, both common and unique microstructural features were found in all three systems.

\section{System I: NiAl-Hf alloys}

\section{As-cast microstructures}

In this system, four single crystal NiAl alloys containing Hf levels of $0.1,0.3,1.0$, and 1.5 (at.\%) were investigated in detail. The optical micrographs of the ascast microstructures for these alloys are shown in Fig. 1. Hafnium-rich particles and interdendritic regions, identified in the SEM, were observed in all the as-cast alloys at levels proportional to the $\mathrm{Hf}$ content. Figure 1(a) shows that as little as 0.1 at. \% $\mathrm{Hf}$ produced Hf-rich regions. Alloys with higher levels of hafnium (i.e., 0.3, 1.0, or 1.5 at. \% $\mathrm{Hf}$ ) clearly showed the interdendritic nature of these Hf-rich regions [Figs. 1(b) -1 (d)]. Higher magnification images of these areas in the 1.0 and 1.5 at. \% Hf alloys, shown in Figs. 2(a) and 2(b), respectively, revealed a semicontinuous phase surrounded by a region with fine striations. The large, semicontinuous interdendritic second phase was identified as the Heusler phase $\mathrm{Ni}_{2}$ AlHf $\left(\beta^{\prime}\right)$ by TEM analysis, and $\mathrm{x}$-ray diffraction. ${ }^{17.18}$ $X$-ray diffraction analysis confirmed the presence of the Heusler phase in the alloy containing 1.5 at. \% Hf. While the interdendritic Heusler phase is present in the other three alloys, it is not present at a level detectable by $\mathrm{x}$-ray diffraction.

The Heusler phase is a ternary compound $\left(\mathrm{Ni}_{2} \mathrm{AlHf}\right)$, with a cubic L2, structure in which the unit cell comprises eight bcc cells with $\mathrm{Al}$ and $\mathrm{Hf}$ atoms occupying two sets of octahedral sites located at body-center sublattice positions. ${ }^{18-20}$ The Heusler phase has a lattice parameter close to two times that of the NiAl matrix (Table II).

The striations observed next to the semicontinuous Heusler interdendritic phase for the NiAl-1 Hf single
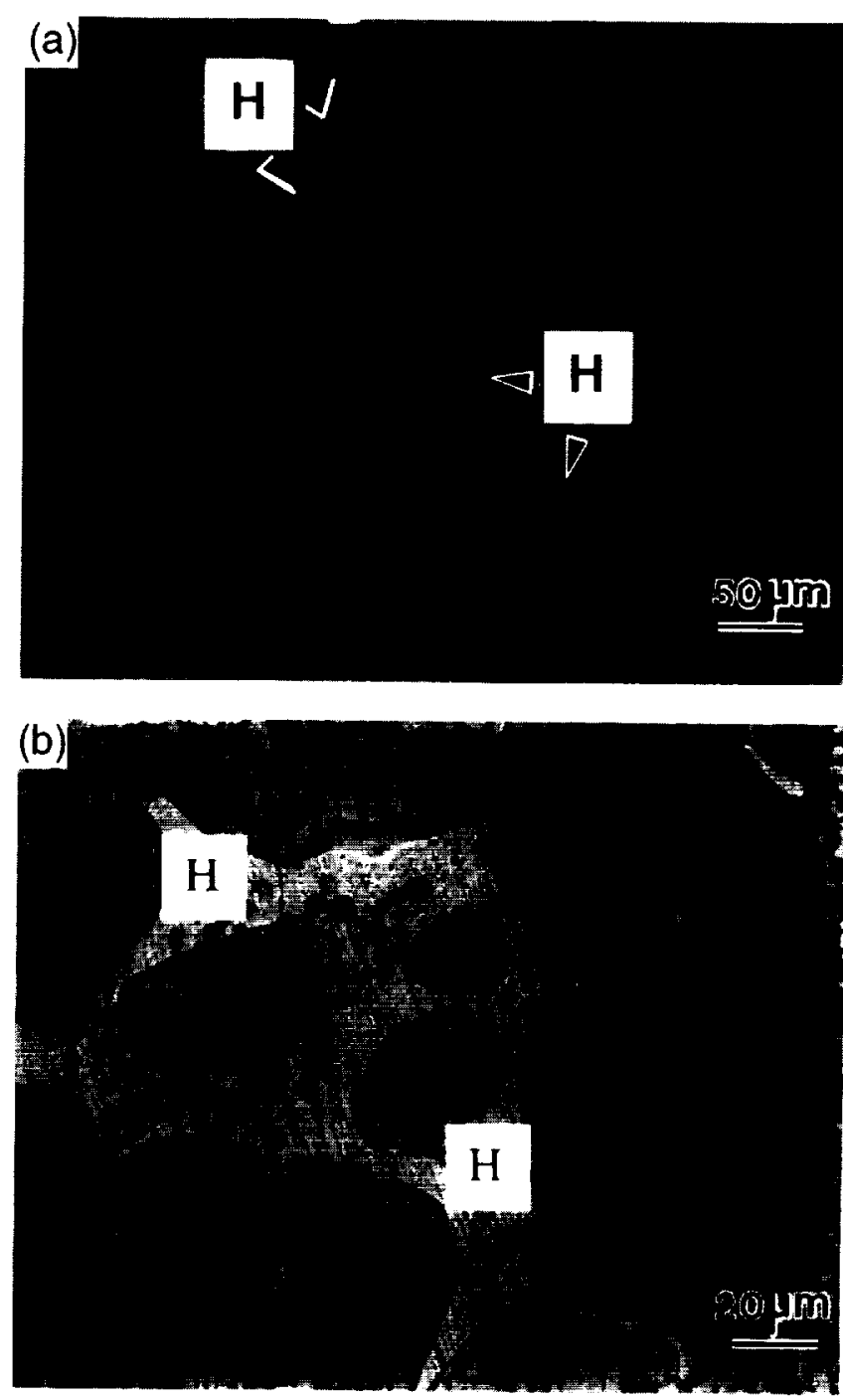

FIG. 2. Optical micrographs of as-cast microstructures of NiAl single crystal alloys containing (a) 1.0, and (b) 1.5 at. \% Hf, showing more details of the Heusler interdendritic regions (indicated by " $\mathrm{H}$ ") and the presence of an acicular streaked phase (G-phase).

TABLE II. Structural comparison between NiAl and Hf-Rich second phases observed in system $\mathrm{I}$.

\begin{tabular}{lclc}
\hline \hline \multicolumn{1}{c}{ Phase } & \multicolumn{1}{c}{$\begin{array}{c}\text { Lattice } \\
\text { parameter }(\mathrm{nm})\end{array}$} & \multicolumn{1}{c}{$\begin{array}{c}\text { Structure } \\
\text { type }\end{array}$} & $\begin{array}{c}\text { No. atoms/ } \\
\text { unit cell }\end{array}$ \\
\hline $\mathrm{NiAl}$ & 0.2883 & $\mathrm{~B} 2(\mathrm{CsCl})$ & 2 \\
$\mathrm{Ni}_{16} \mathrm{HF}_{6} \mathrm{Si}_{7}$ G-phase & 1.1436 & $\mathrm{Mn}_{23} \mathrm{Th}_{6}$ & 116 \\
$\mathrm{Ni}_{2} \mathrm{AlHf}^{\prime} \beta^{\prime}$ & 0.6081 & $\mathrm{BiF}_{3}$ & 16 \\
$\mathrm{NiHfS}^{25}$ & $a=0.639$ & $\mathrm{Co}_{2} \mathrm{Si}$ & 12 \\
& $b=0.389$ & & \\
& $c=0.720$ & & \\
\hline \hline
\end{tabular}

crystal alloy [Figs. 1(c) and 2(a)] and throughout the entire sample of the NiAl-1.5Hf single crystal [Figs. 1(d) and 2(b)], represent fine precipitates identified later by TEM to be a G-phase. A detailed description of the formation and stability of these G-phase precipitates is presented in a following section. 
Differential thermal analysis (DTA) was used to define the melting point of the secondary phases. Figure 3(a) shows DTA curves for heating and cooling of the NiAl-1Hf alloy. Also displayed [Figs. 3(b)-3(f)] are optical micrographs of the samples exposed to different heat-treatment temperatures below, at, and above the melting point of the Heusler phase. It is evident in this sequence of micrographs that the first endothermic peak (centered around $1625 \mathrm{~K}$ ) in the heating curve corresponds to the incipient melting of the interdendritic Heusler phase, evidenced by the round morphology. Likewise, the second curve corresponds to the cooling process, and in this case the peak, starting at $1618 \mathrm{~K}$, indicates the solidification of the interdendritic phase. The larger peaks at $\sim 1900 \mathrm{~K}$ correspond to the melting and the solidification of the NiAl alloy. No other peaks were detected by this technique. The HfNiSi interdendritic phase observed in other single-crystal compositions ${ }^{21}$ was not detected in the alloys presently studied. Based on these results, a homogenization temperature of $1590 \mathrm{~K}$ was chosen to reduce the amount of the primary interdendritic Heusler phase in these alloys and at the same time to avoid the incipient melting of the Heusler phase.

\section{Homogenized microstructure}

To minimize the large degree of interdendritic segregation, all samples were homogenized in argon at $1590 \mathrm{~K}$ for $50 \mathrm{~h}$. After homogenization, the fine Hf-rich pockets observed in the NiAl alloy containing 0.1 at. \% Hf were essentially eliminated. The homogenization heat treatment also greatly reduced the density of the Hfrich interdendritic regions for the $0.3 \mathrm{Hf}$ alloy. In the 1.0 Hf alloy some remnants of the original interdendritic Heusler regions, ranging from 10 to $30 \mu \mathrm{m}$ in size, were still visible [see arrows, Fig. 4(a)], but a homogeneous redistribution of the striations representing the G-phase occurred throughout the whole sample when compared to the as-cast condition [Fig. 2(a)]. In the case of the $1.5 \mathrm{Hf}$ alloy, only a limited decrease in the amount of interdendritic regions as well as some rounding of their boundaries was noticeable [Fig. 4(b)].

\section{Precipitate identification}

Transmission electron microscopy (TEM) was used to identify the fine phase observed optically as striations in these alloys in the as-cast and homogenized

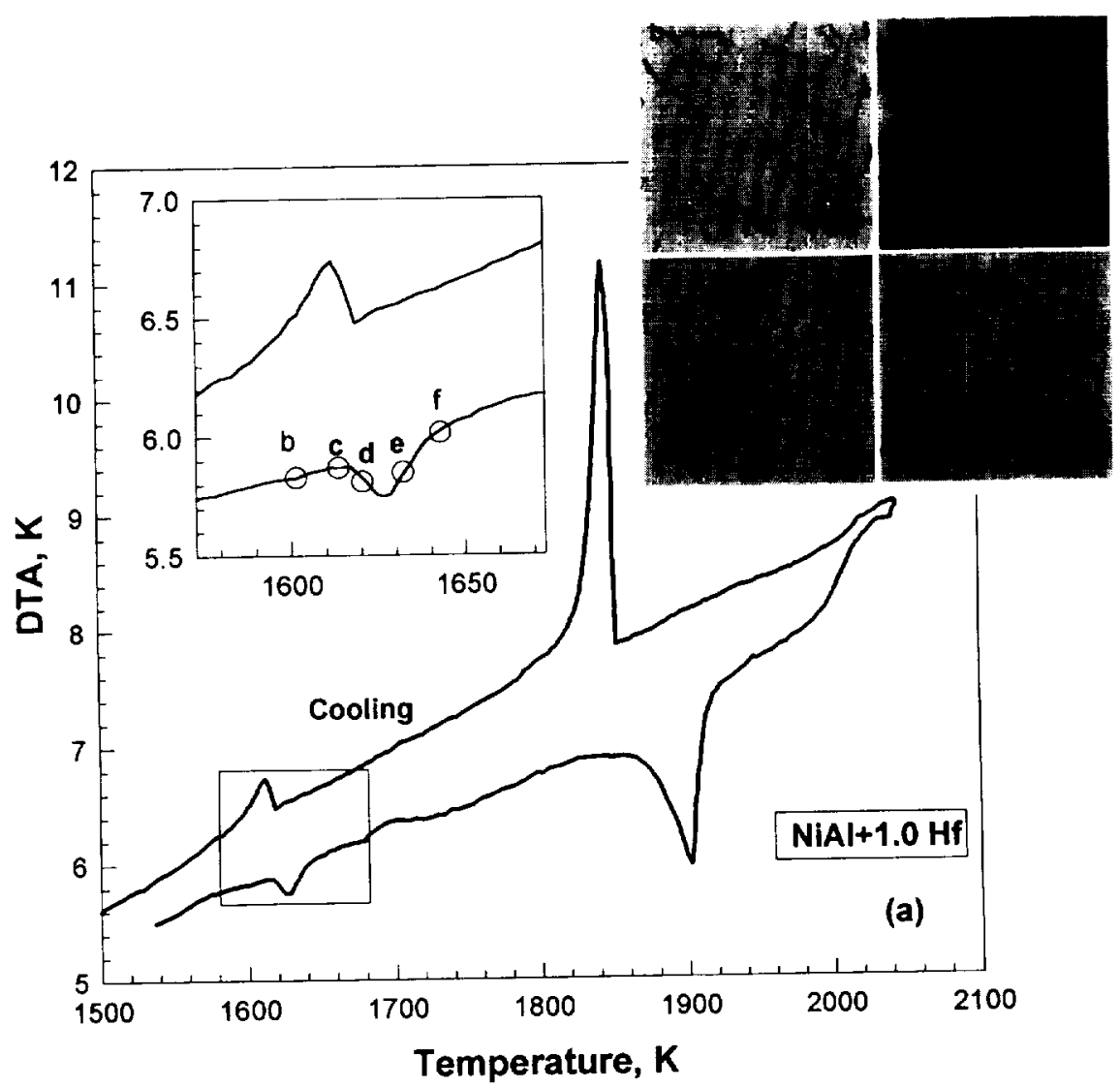

FIG. 3. (a) Differential thermal analysis plot of a NiAl single crystal alloy containing 1 at. \% Hf. Optical micrographs (b-f) correspond to samples that were quenched from 1598 to $1648 \mathrm{~K}$. 

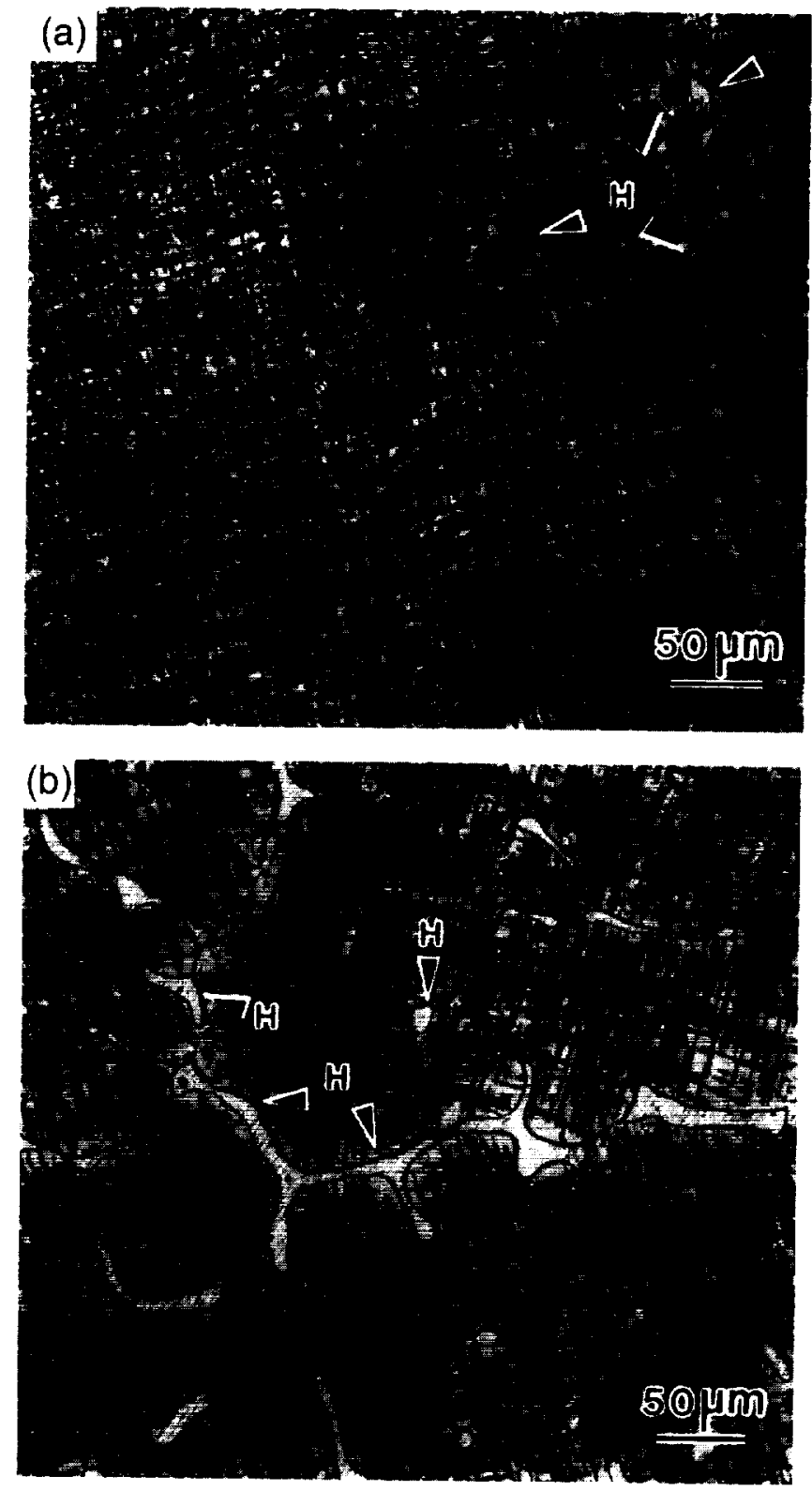

FIG. 4. Optical microstructure of NiAl single crystal alloys containing (a) 1.0 and (b) $1.5 \mathrm{at}$. \% $\mathrm{Hf}$ after the standard homogenization heat treatment, $1590 \mathrm{~K}$ for $50 \mathrm{~h}$ followed by furnace cooling $(10 \mathrm{~K} / \mathrm{min})$.

conditions. Figure 5 shows bright-field (BF) images of the fine phases observed in the NiAl-Hf alloy system after homogenization and furnace cooling (10 $\mathrm{K} / \mathrm{min}$ ). Contrary to what was expected based on the phase diagram, ${ }^{18}$ the precipitates were not the expected Heusler $\left(\mathrm{Ni}_{2} \mathrm{AlHf}\right)$ phase, but instead were found to be rich in $\mathrm{Ni}, \mathrm{Hf}$, and Si using EDXS. Because of the proximity of the $\mathrm{Si} \mathrm{K}_{\alpha}(1.74 \mathrm{keV})$ and $\mathrm{HfM}_{\alpha}(1.645 \mathrm{keV})$ energy peaks, final confirmation of the presence of $\mathrm{Si}$ in these precipitates was accomplished by observations of the same type of precipitates in the $\mathrm{NiAl}-0.05 \mathrm{Zr}$ alloy where no energy peaks overlap exits between the $\mathrm{Zr}$ and $\mathrm{Si}$. Most precipitates were identified as
G-phase $\left(\mathrm{Ni}_{16} \mathrm{Hf}_{6} \mathrm{Si}_{7}\right)^{13,22,23}$; however, in some instances a NiHfSi phase [large dark phase shown in Fig. 5(b)] was also observed. As reported earlier, ${ }^{1+15.24}$ substantial $\mathrm{Si}$, available from the shell mold, has dissolved in the molten metal alloy, resulting in the formation of the fine G-phase or NiHfSi precipitates during solidification and after heat treatments. Figures $6(\mathrm{a})$ and $6(\mathrm{~b})$ show the morphology of the G-phase observed in the NiAl-1Hf alloy after homogenization and furnace cooling. Under the conditions shown in Fig. 6, elongated platelets and small cuboidal G-phase precipitates can be observed. The platelet precipitates are associated with denuded regions, as clearly observed in Fig. 6(b) where the TEM foil was tilted by $\sim 45^{\circ}$ with respect to the image shown in Fig. 6(a). The platelets range from 0.1 to $1 \mu \mathrm{m}$ in length. The finer precipitates, ranging from 5 to $20 \mathrm{~nm}$, are cuboidal in shape as shown in the dark-field (DF) image (Fig. 7), where two faces and one edge of the individual cubes are visible. A corresponding diffraction pattern shown in Fig. 7 is close to the [011] zone axis. These same precipitates existed in the as-cast condition; however, their density varied from region to region due to the inhomogeneous interdendritic segregation [see Fig. 1(c]). These G-phase precipitates were also observed in the 0.1 and $0.3 \mathrm{Hf}$ alloys, although at a reduced density (Fig. 5).

In addition to the G-phase, the NiHfSi phase was mainly observed in the $\mathrm{NiAl}$ alloy containing $0.3 \mathrm{Hf}$ [Figs. 5(b) and 8]. The crystallography of the NiHfSi phase has been described in detail by Garg et al. ${ }^{24}$ The NiHfSi phase has an orthorhombic structure, and its lattice parameters are reported in Table II. ${ }^{25}$ Microdiffraction patterns corresponding to the $[121]_{\mathrm{NiHfS} i}$ and $[131]_{\mathrm{NiHfSi}}$ zone axes are shown in Fig. 8. The finer cubes and platelets of G-phase can also be observed in the background of Fig. 8. The NiHfSi precipitates are about $0.25 \mu \mathrm{m}$ in length as compared to the G-phase, which is about $10 \mathrm{~nm}$ in size. This phase was nonuniformly distributed in the $\mathrm{NiAl}-0.3 \mathrm{Hf}$ alloy, and its presence varied substantially from specimen to specimen.

Homogenization and furnace cooling of the highest Hf-containing $\mathrm{NiAl}$ alloy $(\mathrm{NiAl}-1.5 \mathrm{Hf})$ also resulted in the presence of discontinuous G-phase platelets and cubic precipitates (Fig. 9). Occasionally, the NiHfSi phase was also observed; however, the precipitate density was very low and inhomogeneously distributed. In addition, small Heusler precipitates of size $250 \mathrm{~nm}$ or less were also detected in this alloy. Table II summarizes the structure and lattice parameters of all three types of precipitates detected in the NiAl-Hf system and compares them to $\mathrm{NiAl}$.

\section{System II: NiAl-Zr alloy}

In the early stages of $\mathrm{NiAl}$ alloy development, $\mathrm{Zr}$ was a common addition because of its beneficial effect 

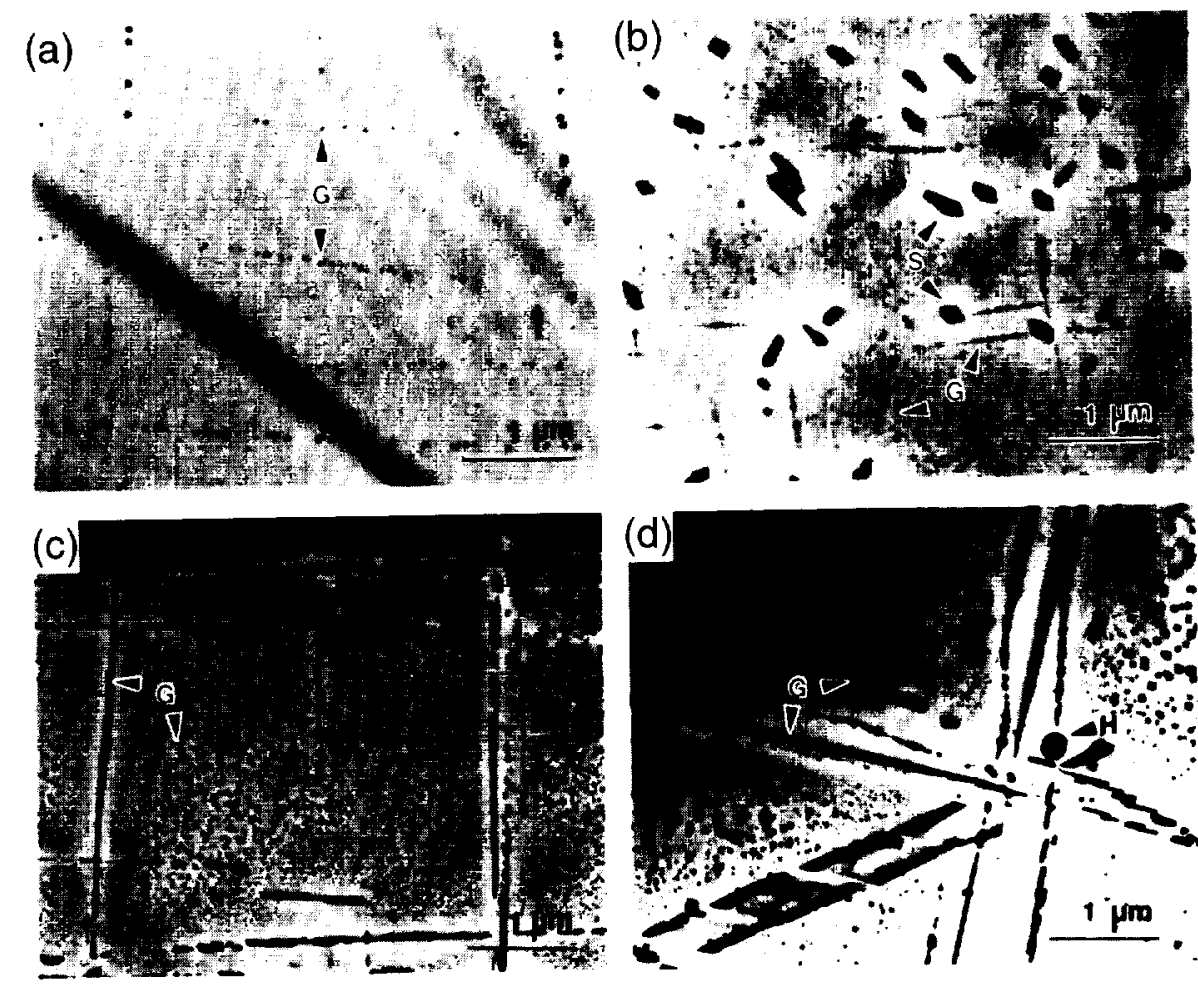

FIG. 5. TEM BF images of the fine $\mathrm{Hf}, \mathrm{Si}$, and $\mathrm{Ni}$ rich phases observed in the $\mathrm{NiAl}-\mathrm{Hf}$ alloy systems after homogenization and furnace cooling ( $10 \mathrm{~K} / \mathrm{min}$ ). (a) $0.1 \mathrm{Hf}$ : G-phase (G); (b) $0.3 \mathrm{Hf}$ : G-phase (G) and NiHfSi (S); (c) $1.0 \mathrm{Hf}$ : G-phase (G); and (d) $1.5 \mathrm{Hf}$ : G-phase (G), Heusler (H), and NiHfSi (not observed in this area).

on the cyclic oxidation behavior of this intermetallic alloy. While the effect of $\mathrm{Zr}$ on the oxidation behavior of polycrystalline and single crystal $\mathrm{NiAl}$ has been studied in detail, ${ }^{1.2}$ the effect of $\mathrm{Zr}$ on the microstructure of $\mathrm{NiAl}$ has generally been ignored. Since only small additions of $\mathrm{Zr}$ were added to single crystal $\mathrm{NiAl}$ alloys, the resultant microstructure in the as-cast condition does not show the large interdendritic regions observed in the as-cast $\mathrm{NiAl}-\mathrm{Hf}$ system. However, fine $\mathrm{G}$-phase $\left(\mathrm{Ni}_{16} \mathrm{Zr}_{6} \mathrm{Si}_{7}\right)$ precipitates were present in this system. Figure 10 shows a BF image of the G-phase precipitates observed in a homogenized and furnace-cooled $\mathrm{NiAl}-0.05 \mathrm{Zr}$ single crystal alloy. Even though only 0.05 at. \% $\mathrm{Zr}$ was present in this alloy, the density of G-phase was much greater than that observed in the 0.1 at. \% Hf alloy [Fig. 5(a)]. In both systems the G-phase precipitates have the same type of morphology, i.e., cubes and platelets.

The lattice parameter for $\mathrm{Ni}_{16} \mathrm{Zr}_{6} \mathrm{Si}_{7}$ (Table III) was measured to be $1.15 \mathrm{~nm}$, as determined from electron diffraction patterns of the precipitates and the NiAl matrix and using the lattice parameter of $\mathrm{NiAl}$ (determined by $x$-ray diffraction) to be $0.2883 \pm 0.0001 \mathrm{~nm}$ as a reference. This is in good agreement with previously reported values ${ }^{22,23}$ and indicates that the G-phase lattice parameter is close to four times that of the $\mathrm{NiAl}$ matrix. The diffraction patterns shown in Figs. 11(a) and 11 (b) for the [001] and [111] zone axes demonstrate the close lattice matching and an orientation relationship between the matrix (intense reflections) and the precipitates (both weak and intense reflections). The lattice misfit between the matrix and G-phase precipitate for the $\mathrm{NiAl}-\mathrm{Zr}$ system is about $-0.5 \%$ and is somewhat larger $(-0.8 \%)$ in absolute value for the $\mathrm{NiAl}-\mathrm{Hf}$ system. A single variant orientation relationship was observed between the NiAl matrix and the G-phase precipitates, given as: $\{100\}_{\mathrm{G}} \|\{100\}_{\mathrm{NiAl}}$ and $[010]_{\mathrm{G}} \|[010]_{\mathrm{NiAl}}$. In other words, the fcc lattice of the precipitate is parallel to the ordered bcc lattice of the $\mathrm{NiAl}$ (a cube-on-cube relationship). The $\mathrm{G}$-phase nucleates with a $\{100\}_{\mathrm{NiAl}}$ habit plane. In some cases dislocations on $\{100\}_{\mathrm{NiAl}}$ planes provide preferential nucleation sites for G-phase precipitation and might responsible for the platelets formation. This special orientation relationship, the very small lattice misfit, and the absence of any observable misfit dislocations indicates that the G-phase cuboids are coherent with the NiAl matrix.

Two alloys with stoichiometries equivalent to the $\mathrm{Hf}$ and $\mathrm{Zr}$ containing G-phases $\left(\mathrm{Ni}_{16} \mathrm{Zr}_{6} \mathrm{Si}_{7}\right.$ and $\left.\mathrm{Ni}_{16} \mathrm{Hf}_{6} \mathrm{Si}_{7}\right)$ were arc-melted and cast in a copper mold to determine their melting points by DTA and lattice parameters using $\mathrm{x}$-ray diffraction techniques. The solidus and liquidus temperature of the $\mathrm{Zr}$-containing G-phase alloy are approximately 1797 and $1820 \mathrm{~K}$, respectively. Table III reports the lattice parameters of the $\mathrm{Zr}$ and $\mathrm{Hf}$-based $\mathrm{G}$-phases plus other reported G-phases that may form in alloyed NiAl single crystals with $\mathrm{Si}$ impurities. 


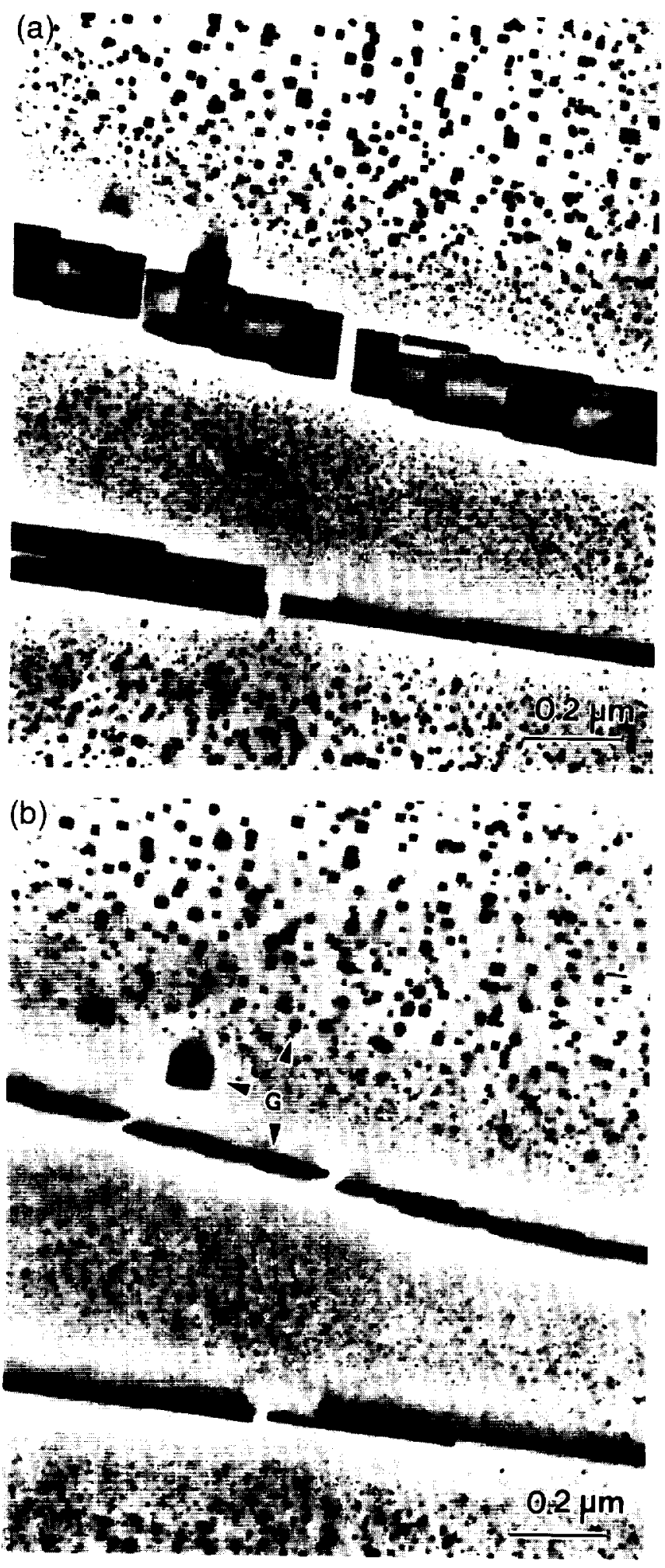

FIG. 6. (a) TEM BF image of $\mathrm{Ni}_{16} \mathrm{Hf}_{6} \mathrm{Si}_{7}$ (G-phase) platelet and cuboidal precipitates observed in a single crystal NiAl-1 at. \% $\mathrm{Hf}$ specimen annealed at $1590 \mathrm{~K}$ for $50 \mathrm{~h}$ and furnace cooled. (b) TEM BF image of the same area, but foil was tilted by $45^{\circ}$ with respect to the position shown in Fig. 6(a).

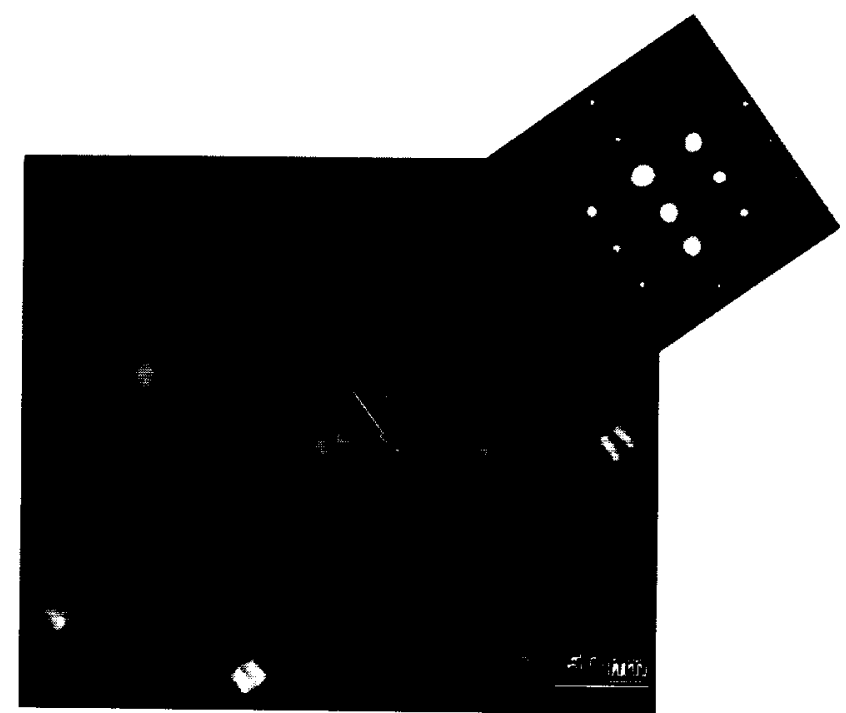

FIG. 7. TEM DF image of cuboidal $\mathrm{Ni}_{16} \mathrm{Hf}_{6} \mathrm{Si}_{7}$ (G-phase) precipitates imaged close to the $[011]$ zone axis in a $\mathrm{NiAl}-1 \mathrm{Hf}$ single crystal alloy showing cube faces viewed edge-on.
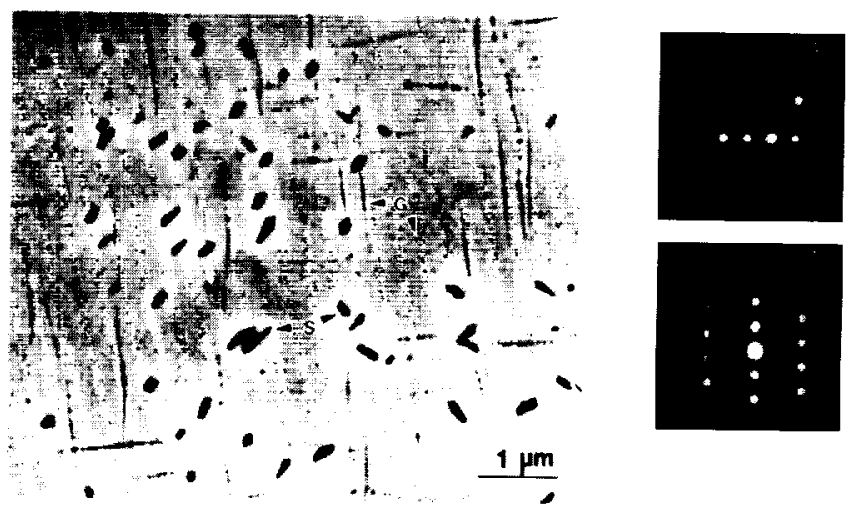

FIG. 8. TEM BF image showing the NiHfSi phase (larger parallepided shaped particles) observed in the NiAl-0.3 at. \% Hf alloy after homogenization and furnace cooling. In the background $\mathrm{G}$-phase cubes and platelets $\left(\mathrm{Ni}_{16} \mathrm{Hf}_{6} \mathrm{Si}_{7}\right)$ are also imaged. Microdiffraction patterns corresponding to $\mid 121]$ and $[13 \|]$ zone axes of the NiHfSi phase are also shown.

\section{System III: $\mathrm{NiAl}-\mathrm{Hf}-\mathrm{Zr}$ alloy}

This system was studied to investigate the resultant microstructure when $\mathrm{Hf}$ and $\mathrm{Zr}$ are both present in a single crystal alloy. The ingot produced by this technique had a large amount of interdendritic segregation, similar in microstructure to the $\mathrm{NiAl}-1 \mathrm{Hf}$ alloy. The microstructure was examined in detail after the homogenization and furnace cooling treatment given to all the alloys. As shown in Fig. 12(a), this treatment resulted not only in the formation of G-phase ( 10 to $40 \mathrm{~nm}$ cubes and 0.25 to $3.5 \mu \mathrm{m}$ platelets), but also in the formation of some Heusler precipitates (50 to $150 \mathrm{~nm}$ in diameter). This combination of precipitates was not observed in the alloys containing low levels of $\mathrm{Hf}(0.1$ to $1 \mathrm{Hf})$ or $\mathrm{Zr}$ after the original homogenization treatment. The Heusler 

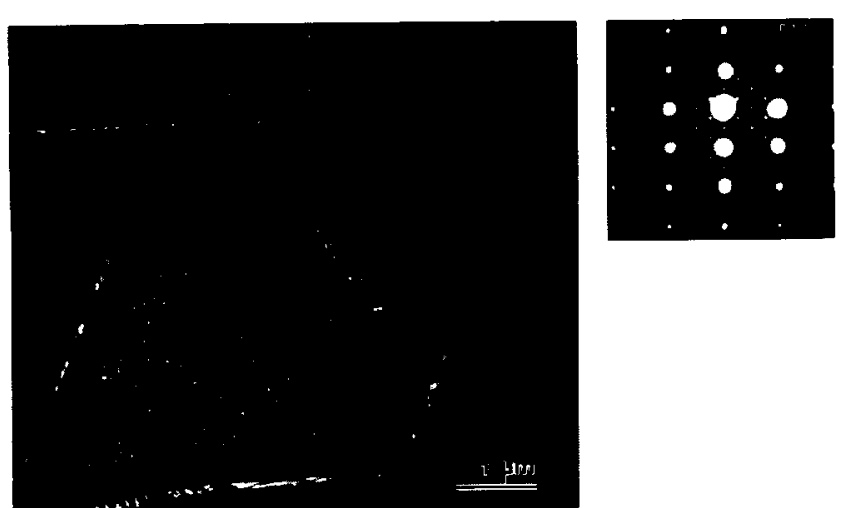

FIG. 9. TEM DF image close to a $[011]$ zone axis showing the distribution and morphology of $\mathrm{G}$-phase $\left(\mathrm{Ni}_{16} \mathrm{Hf}_{6} \mathrm{Si}_{7}\right)$ in the $\mathrm{NiAl}$ 1.5 at. \% Hf alloy after homogenization and furnace cooling.

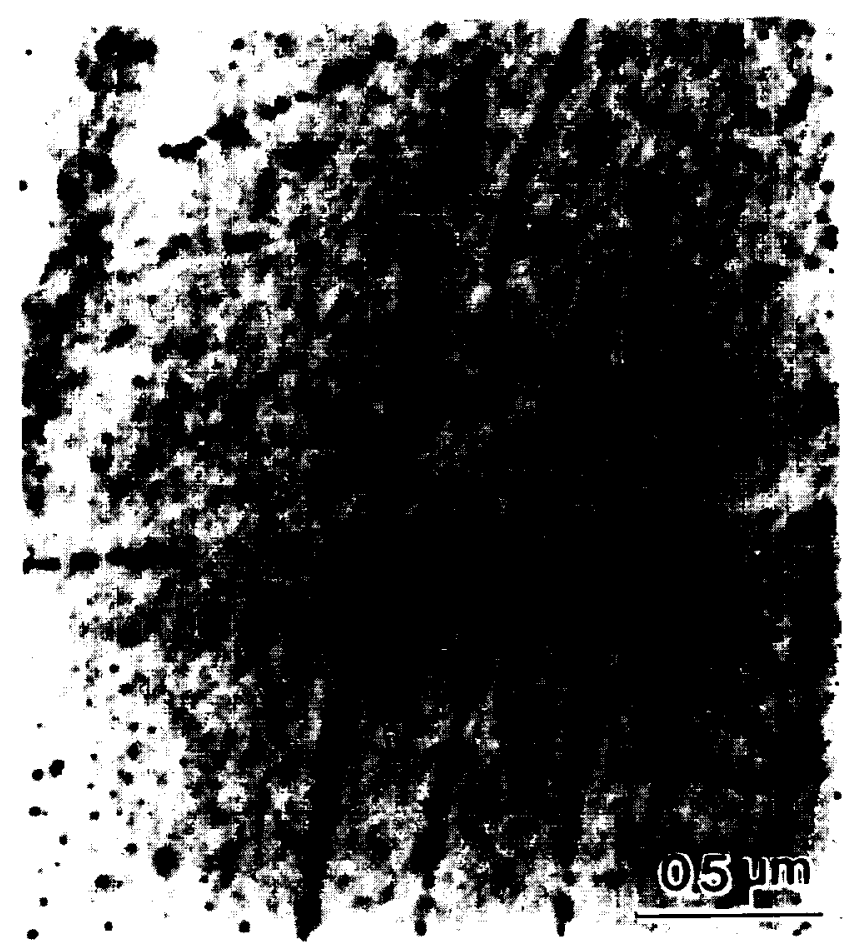

FIG. 10. TEM BF of G-phase precipitates observed in the NiAl0.05 at. \% $\mathrm{Zr}$ alloy after homogenization and furnace cooling.

precipitates were generally concentrated preferentially at the G-phase platelet sites [Fig. 12(b)], similar to the observed aged structures discussed in Sec. D. The Heusler phase has a lattice misfit with NiAl much larger than the G-phase $(5 \%$ compared to $-0.8 \%$ for the G-phase). The Heusler phase is semicoherent and nucleates heterogeneously on $\{100\}_{\text {NiAl }}$ planes with a cubeon-cube orientation relationship with the $\mathrm{NiAl}$ matrix. The large misfit between the precipitate and the matrix is accommodated by a square array of misfit dislocations (spacing $5.6 \mathrm{~nm}$ ) at the particle-matrix interface which are clearly seen on the $\{100\}$ face of $\beta^{\prime}$ precipitates in a $\langle 001\rangle_{\text {NiAl }}$ orientation [Fig. 12(c)].
TABLE III. Possible G-phases in NiAl.

\begin{tabular}{|c|c|c|}
\hline Phase & Lattice parameter (nm) & Structure type \\
\hline $\mathrm{Ni}_{10} \mathrm{Zr}_{6} \mathrm{Si}_{7}$ & $\begin{array}{l}1.147 \pm 0.01 \\
1.1423 \\
1.1478 \pm 0.005\end{array}$ & $\begin{array}{l}\text { Gladyshevkii ef al. }(1961)^{22} \\
\text { Spiegel ot al. }(1963)^{23} \\
\text { This work (x-ray) }\end{array}$ \\
\hline $\mathrm{Ni}_{10}, \mathrm{Ht}_{6}, \mathrm{Si}^{7}$ & $\begin{array}{l}1.139 \pm 0.01 \\
1.1436 \pm 0.006\end{array}$ & $\begin{array}{l}\text { Gladyshevkii et al. (1961) } \\
\text { This work (x-ray) }\end{array}$ \\
\hline $\begin{array}{l}\mathrm{Ni}_{1,}, \mathrm{Si}_{6} \mathrm{Si}_{7} \\
\mathrm{Ni}_{16} \mathrm{Nb}_{6} \mathrm{Si}_{7}\end{array}$ & $\begin{array}{l}1.1460 \\
1.1240 \pm 0.01 \\
1.1249\end{array}$ & 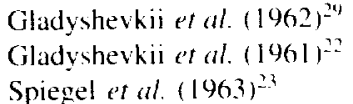 \\
\hline $\begin{array}{l}\mathrm{Ni}_{16} \mathrm{Ti}_{6,6} \mathrm{Si}_{7} \\
\mathrm{Ni}_{16} \mathrm{Ti}_{6}, \mathrm{Si}_{7} \\
\mathrm{Ni}_{16} \mathrm{Cr}_{6} \mathrm{Si}_{7} \\
\mathrm{Ni}_{16} \mathrm{~V}_{6} \mathrm{Si}_{7}\end{array}$ & $\begin{array}{l}1.1215 \\
1.1220 \\
1.110 \\
1.1153\end{array}$ & $\begin{array}{l}\text { Spiegel et al. }(1963)^{23} \\
\text { Spiegel et al. }(1963)^{23} \\
\text { Gladyshevkii et al. }(196.3)^{311} \\
\text { Spiegel et al. }(196.3)^{23}\end{array}$ \\
\hline
\end{tabular}

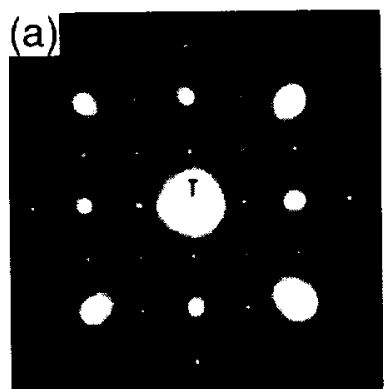

(c)

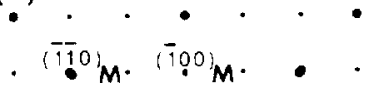

$$
\begin{aligned}
& \text {. . . . . } .
\end{aligned}
$$

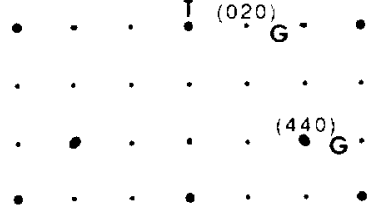

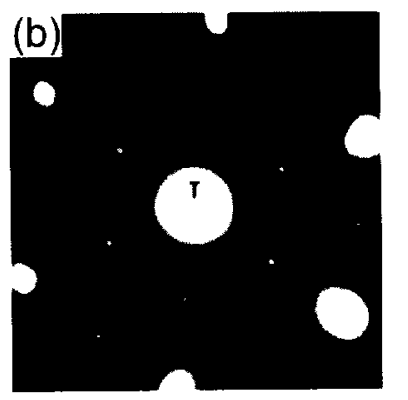

(d)

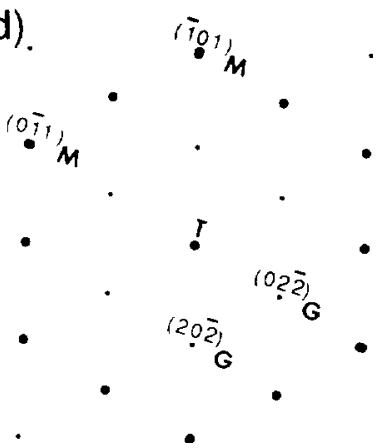

FIG. 11. (a, b) actual and (c, d) simulated $|(0) 1|$ and $|111|$ zone axes diffraction patterns of the $\mathrm{Ni}_{1 \times} \mathrm{Zr}_{6} \mathrm{Si}_{7}$ G-phase and $\mathrm{NiAl}$ matrix observed in the $\mathrm{NiAl}-0.05$ at. \% $\mathrm{Zr}$ alloy demonstrating the close precipitate and matrix lattice matching $\left(a_{(\mathrm{i} \text {. phase }} \approx 4 \times a_{\left.\mathrm{NiA}_{\mathrm{N}}\right)}\right)$.

\section{Effect of cooling rate}

The NiAl-Hf alloys were chosen to explore the effect of various cooling rates on the formation and morphology of the precipitates after the homogenization heat treatment. Three different cooling rates, controlled furnace cooling $(10 \mathrm{~K} / \mathrm{min})$, air cooling. and water quenching, were used for this purpose. Cooling rate had a significant effect on the distribution and size of the G-phase precipitates. Air cooling produced a fine and uniform distribution of cuboidal G-phase precipitates $(\leqslant 10 \mathrm{~nm})$ in the $\mathrm{NiAl}-0.3 \mathrm{Hf}[\mathrm{Fig} .13(\mathrm{a})]$ and $\mathrm{NiAl}-1 \mathrm{Hf}$ alloys [Fig. 13(b)] and a complete absence of the platelet morphology that was observed in the furnace-cooled samples (Fig. 6). Re-solutioning a 

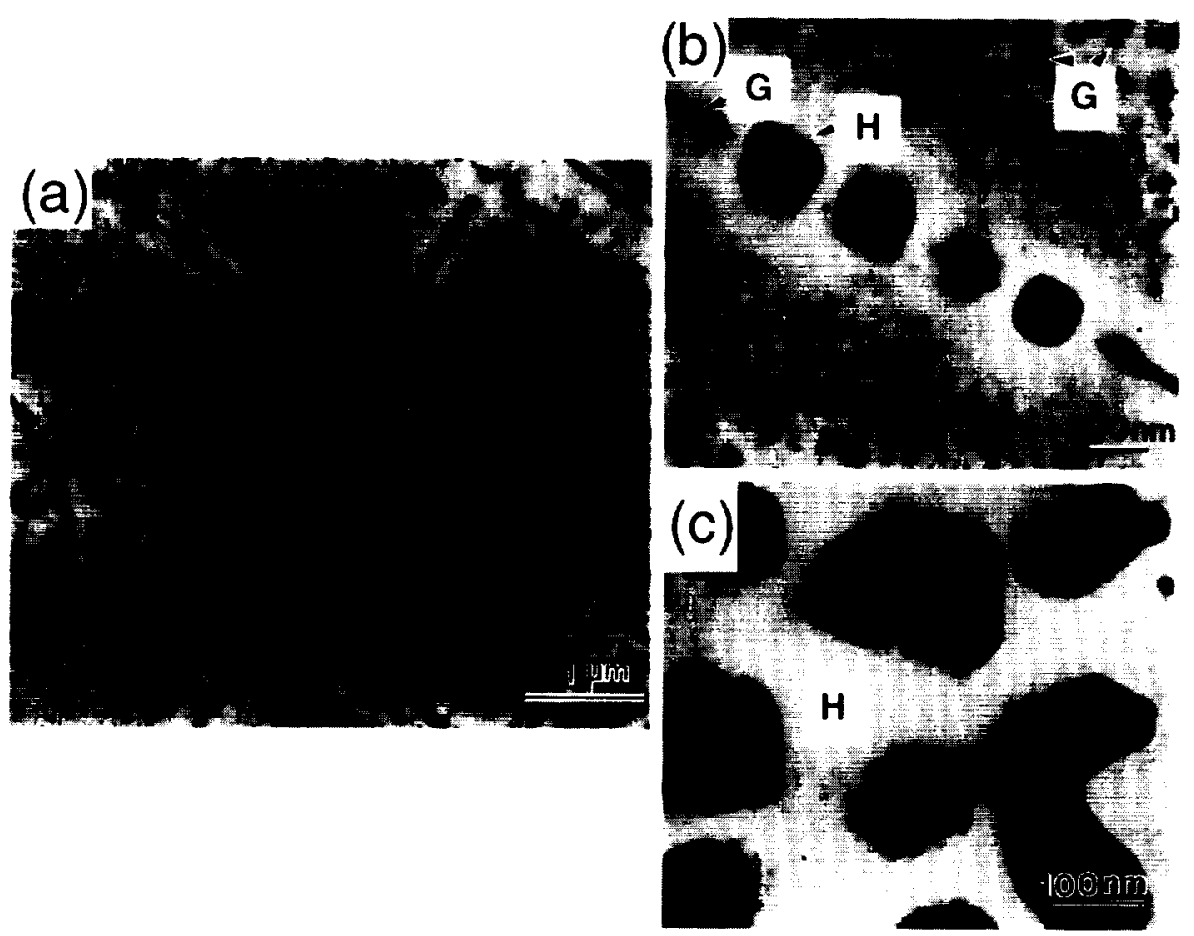

FIG. 12. (a) TEM BF images of G-phase and Heusler precipitates observed in the NiAl-Hf-Zr alloy after the standard homogenization heat treatment followed by furnace cooling. (b) Higher magnification showing that the Heusler phase forms preferentially at the G-phase platelet sites. (c) A square network of misfit dislocations observed at the Heusler particle-matrix interface close $10\langle 001\rangle_{\mathrm{NiAl}}$ zone axis.

homogenized and furnace-cooled $\mathrm{NiAl}-1 \mathrm{Hf}$ sample by reheating to $1590 \mathrm{~K}$ for only $20 \mathrm{~min}$, followed by air cooling, produced a microstructure similar to that shown in Fig. 13(b), indicating that the dissolution of the G-phase, both platelets and cuboids, occurs rapidly.

Air cooling completely eliminated the G-phase platelets and the NiHfSi phase that were previously observed in the $\mathrm{NiAl}-0.3 \mathrm{Hf}$ alloy after furnace cooling (Fig. 8). Moreover, faster cooling rates, such as water quenching, completely suppressed the formation of the G-phase, resulting in a single phase B2 NiAl with no second phases, other than the interdendritic regions. These observations indicate that the G-phase precipitates completely dissolve at $1590 \mathrm{~K}$ and then may reprecipitate during cooldown. The cooling rates control the formation, size, morphology, and distribution of the G-phase precipitates, suggesting that these characteristics can be optimized through proper control.

\section{Aging studies: Stability of secondary phases}

\section{System I: NiAl-Hf alloys}

Figure 14 shows the microstructures observed in the homogenized and air cooled $\mathrm{NiAl}-1 \mathrm{Hf}$ alloy after aging samples at $1300 \mathrm{~K}$ for 1,100 , and $500 \mathrm{~h}$. Figure 14(a) shows the presence of an additional phase that appears after only $\mathrm{l} h$ of aging and continues to grow with aging time. A microdiffraction pattern along the [001] zone axis from one of the larger precipitates in Fig. 14(c) identifies these precipitates as the expected Heusler phase. In the background, the finer G-phase precipitates can be clearly seen after $1 \mathrm{~h}$ of aging [Fig. 14(a)]. Denuded regions are always associated with the larger Heusler particles. This is an indication that some G-phase precipitates have dissolved in favor of the Heusler precipitates. At an intermediate aging time of $100 \mathrm{~h}$ the Heusler precipitates coalesced into a "worm-like" morphology, while the density of G-phase precipitates was reduced further [Fig. 14(b)]. After $500 \mathrm{~h}$, larger and more equiaxed Heusler precipitates were formed [Fig. 14(c)] and very few G-phase precipitates were visible. In contrast to the Heusler particles that coarsened as a function of time, the G-phase did not coarsen appreciably. Instead, the G-phase particles appeared to dissolve in favor of the $\beta^{\prime}$-precipitates.

Aging the $\mathrm{NiAl}-1 \mathrm{Hf}$ alloy at $1300 \mathrm{~K}$ for $1 \mathrm{~h}$ after homogenization and furnace cooling also resulted in the formation of $\beta^{\prime}$ precipitates, but in this case, they preferentially nucleated at the G-phase platelet sites, as shown in Fig. 15. Again, misfit dislocations at the precipitate-matrix interface are visible. The G-phase platelets seem to be heterogeneous nucleation sites for the Heusler precipitate formation. This was also the case for the homogenized $\mathrm{NiAl}-\mathrm{Hf}-\mathrm{Zr}$ alloy shown in Fig. 12.

Microhardness values and Heusler precipitate sizes for various cooling rate conditions and different stages of aging at $1300 \mathrm{~K}$ are summarized in Fig. 16. The highest 

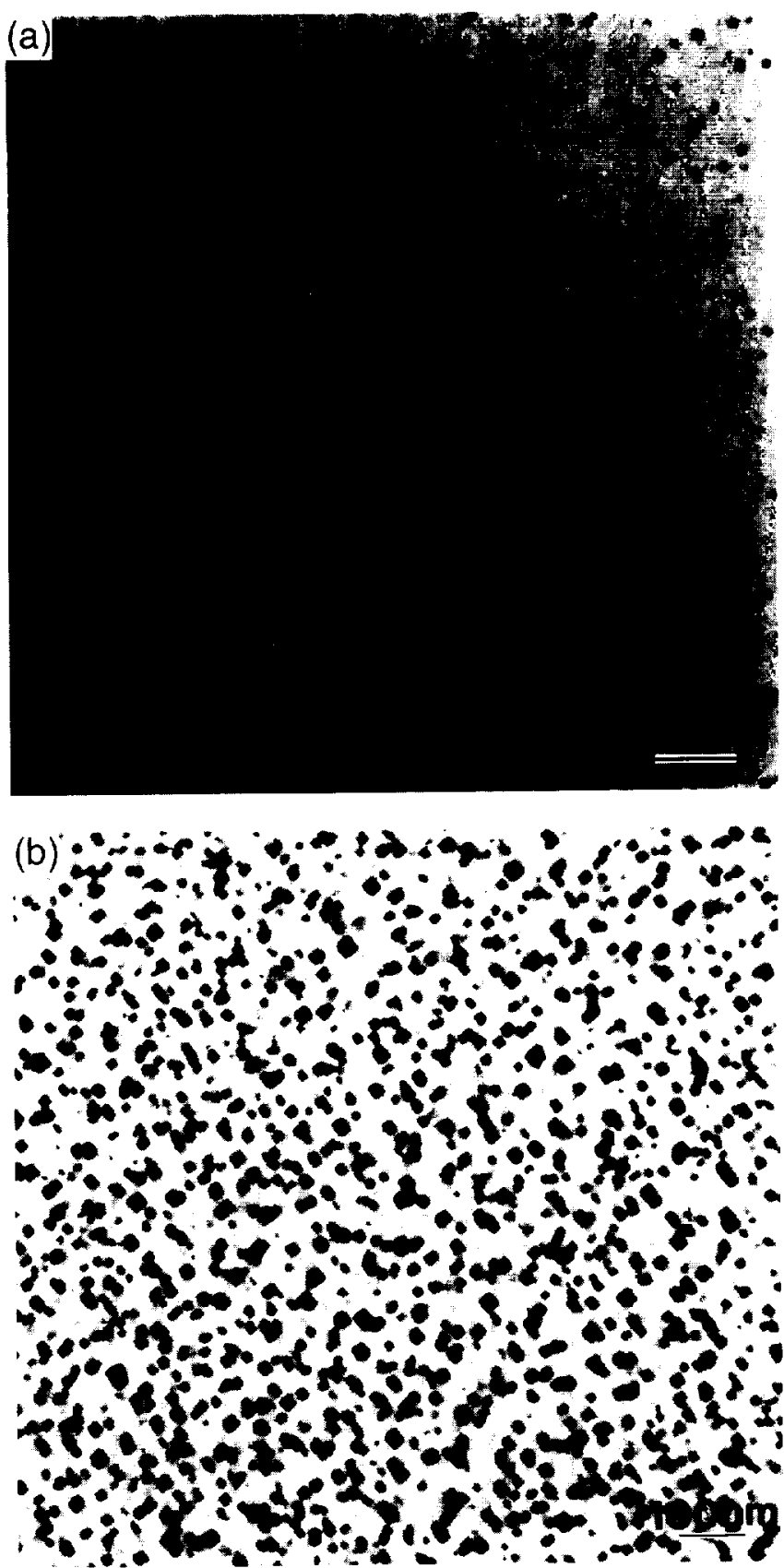

FIG. 13. TEM BF images of G-phase precipitates observed in the (a) $\mathrm{NiAl}-0.3$ at. \% $\mathrm{Hf}$ and (b) $\mathrm{NiAl}-1.0$ at. \% $\mathrm{Hf}$ alloys after the standard homogenization heat treatment followed by air cooling. Only finer $G$-phase cubes formed under this condition.

hardness values correspond to the $\mathrm{NiAl}-1 \mathrm{Hf}$ alloy (the $\mathrm{NiAl}-1.5 \mathrm{Hf}$ was not examined) in either the air-cooled or water-quenched condition. In the air-cooled sample, Heusler precipitates were not present and G-phase precipitates were cuboidal in shape and homogeneously distributed in the matrix (Fig. 13), whereas no precipitates were detectable by TEM after water quenching. Furnace cooling, which produced a mixed distribution of cuboidal G-precipitates and platelets (Fig. 6), shows a lower microhardness value than the air cooled or water-quenched conditions. Microhardness values progressively decreased as a function of $1300 \mathrm{~K}$ aging time. Microhardness values for the NiAl alloys containing 0.3 and 0.1 at. $\% \mathrm{Hf}$ in the as-homogenized and furnace-cooled condition are also included in Fig. 16. As expected, lower additions of $\mathrm{Hf}$ resulted in lower microhardness values.

Aging the $\mathrm{NiAl}-1 \mathrm{Hf}$ alloy at $1400 \mathrm{~K}$ for $20 \mathrm{~h}$ after the standard homogenization heat treatment resulted in the formation of $\beta^{\prime}$ Heusler precipitates and complete dissolution of the G-phase precipitates. Figure 17(a) corresponds to a region where Heusler probably formed at the expense of the original G-phase platelets. since the spacing between the rows of Heusler precipitates corresponds approximately to the spacing between the G-phase platelets prior to the aging heat treatment.

In contrast, long-term aging of the $\mathrm{NiAl}-0.3 \mathrm{Hf}$ alloy at $1300 \mathrm{~K}$ for $168 \mathrm{~h}$ after homogenization and furnace cooling (condition shown in Fig. 8), resulted in the complete dissolution of the G-phase with only NiHfSi precipitates remaining [Fig. 17(b)]. No $\beta^{\prime}$ precipitates were observed in the regions analyzed.

\section{System II: NiAl-Zr alloy}

Aging of the homogenized and furnace-cooled $\mathrm{NiAl}-0.05 \mathrm{at} \% \mathrm{Zr}$ alloy at $1.300 \mathrm{~K}$ for $168 \mathrm{~h}$ resulted in the formation of the NiZrSi phase and the complete dissolution of the G-phase precipitates as shown in Fig. 17(c). Similar to the NiHfSi phase, observed in some of the NiAl-Hf alloys, NiZrSi has an orthorhombic structure with lattice parameters, $a=0.647 \mathrm{~nm}, b=$ 0.3815 , and $c=0.7263 \mathrm{~nm}^{26}$

\section{System III: NiAl-Hf-Zr alloy}

Aging of the homogenized and furnace-cooled $\mathrm{NiAl}-1 \mathrm{Hf}-0.2 \mathrm{Zr}$ alloy at $1300 \mathrm{~K}$ for only $1 \mathrm{~h}$ resulted in the complete dissolution of the G-phase, with only aligned $\beta^{\prime}$ Heusler precipitates left, as shown in Fig. $17(\mathrm{~d})$.

\section{DISCUSSION}

Microstructural characterization of single crystal $\mathrm{NiAl}$ alloys with reactive element additions of $\mathrm{Hf}$ and $\mathrm{Zr}$ was carried out using different degrees of resolution. Optical and SEM techniques were useful in imaging and analyzing the larger regions of interdendritic segregation present in these systems, whereas TEM was required to resolve and ascertain the finer phases formed during the various heat treatments. All these results are summarized in Table IV. As expected, the amount of interdendritic segregation after directional solidification was proportional to the level of alloying 
TABLE IV. Summary of observed microstructures.

\begin{tabular}{|c|c|c|c|c|}
\hline $\begin{array}{l}\text { System studied } \\
\text { Alloy (in at. \%) }\end{array}$ & As-cast & Homogenized & $\begin{array}{c}\text { Short time aging } \\
\text { (after homogenization) }\end{array}$ & $\begin{array}{l}\text { Long time aging } \\
\text { (after homogenization) }\end{array}$ \\
\hline \multicolumn{5}{|l|}{ System I } \\
\hline $\begin{array}{l}\mathrm{NiAl}-1.5 \mathrm{Hf} \\
\mathrm{Hf}: \mathrm{Si}=7.5\end{array}$ & $\begin{array}{l}\text { - Large amount } \\
\text { interdendritic } \beta^{\prime} \\
\text { - G-phase: cubes and long } \\
\text { platelets } \\
\text { - Few fine } \beta^{\prime} \text { and NiHfSi }\end{array}$ & $\begin{array}{l}\text { Large amount interdendritic } \\
\beta^{\prime}-\text { some rounding } \\
\text { Furnace cooled: } \\
\text { G-phase: cubes and long } \\
\text { platelets } \\
\text { - Few fine } \beta \text { and NiHfSi }\end{array}$ & Not studied & Not studied \\
\hline $\begin{array}{l}\mathrm{NiAl}-1 \mathrm{Hf} \\
\mathrm{Hf}: \mathrm{Si}=7.5\end{array}$ & $\begin{array}{l}\text { - Large amount } \\
\text { interdendritic } \beta^{\prime} \\
\text { - Localized G-phase: cubes } \\
\text { and platelets }\end{array}$ & $\begin{array}{l}\text { Reduced interdendritic } \beta \\
\text { Furnace cooled: } \\
\text { - G-phase: cubes and long } \\
\text { platelets } \\
\text { Air cooled: } \\
\text { G-phase: fine cubes } \\
\text { Water quenched: } \\
\text { No precipitates }\end{array}$ & $\begin{array}{l}\text { 1300 K aging: } \\
\text { - If initially Homog. }+ \\
\text { furnace cooled: } \\
\beta^{\prime} \text { precipitates nucleating } \\
\text { preferentially at G-phase } \\
\text { platelet sites } \\
\text { - If initially Homog. + air } \\
\text { cooled: } \\
\text { Homogeneous nucleation } \\
\text { of } \beta^{\prime} \\
1400 \mathrm{~K} \text { aging: } \\
\text { - } \beta^{\prime} \text { formation } \\
\text { - Complete dissolution of } \\
\text { G-phase }\end{array}$ & $\begin{array}{l}1300 \mathrm{~K} \text { aging: } \\
\text { Large } \beta^{\prime} \text { precipitates } \\
\text { - Almost complete } \\
\text { dissolution of G-phase }\end{array}$ \\
\hline $\begin{array}{l}\mathrm{NiAl}-0.3 \mathrm{Hf} \\
\mathrm{Hf}: \mathrm{Si}=0.43\end{array}$ & $\begin{array}{l}\text { - Large amount } \\
\text { interdendritic } \beta^{\prime} \\
\text { - Localized G-phase: } \\
\text { mostly cubes and some } \\
\text { platelets }\end{array}$ & $\begin{array}{l}\text { - Greatly reduced } \\
\text { interdendritic } \beta^{\prime} \\
\text { Furnace cooled: } \\
\text { G-phase: cubes and } \\
\text { platelets and clusters of } \\
\text { NiHfSi precipitates } \\
\text { Air cooled: } \\
\text { - G-phase: fine cubes }\end{array}$ & Not studied & $\begin{array}{l}\text { 1300 K aging: } \\
\text { - Complete dissolution of } \\
\text { G-phase } \\
\text { - Only NiHfSi precipitates } \\
\text { present } \\
\text { - No } \beta^{\prime}\end{array}$ \\
\hline $\begin{array}{l}\mathrm{NiAl}-0.1 \mathrm{Hf} \\
\mathrm{Hf}: \mathrm{Si}=0.43\end{array}$ & $\begin{array}{l}\text { - Small amount of } \\
\text { interdendritic } \beta^{\prime} \\
\text { - G-phase: mostly cubes, } \\
\text { random distribution }\end{array}$ & $\begin{array}{l}\text { - Minimal interdendritic } \beta^{\prime} \\
\text { Furnace cooled: } \\
\text { - G-phase: fine cubes }\end{array}$ & Not studied & Not studied \\
\hline \multicolumn{5}{|l|}{ System II } \\
\hline $\begin{array}{l}\mathrm{NiAl}-0.05 \mathrm{Zr} \\
\mathrm{Zr}: \mathrm{Si}=0.33\end{array}$ & $\begin{array}{l}\text { - No interdendritic } \beta^{\prime} \\
\text { - G-phase precipitates, } \\
\text { cubes, and some } \\
\text { platelets }\end{array}$ & $\begin{array}{l}\text { Furnace cooled: } \\
\text { - G-phase cubes and some } \\
\text { platelets }\end{array}$ & Not studied & $\begin{array}{l}1300 \mathrm{~K} \text { aging: } \\
\text { - Complete dissolution of } \\
\text { G-phase } \\
\text { - Only NiZrSi precipitates } \\
\text { present } \\
\text { - No } \beta^{\prime}\end{array}$ \\
\hline \multicolumn{5}{|l|}{ System III } \\
\hline $\begin{array}{l}\mathrm{NiAl}-1 \mathrm{Hf}-0.2 \mathrm{Zr} \\
\mathrm{Hf}+\mathrm{Zr}: \mathrm{Si}=6.9\end{array}$ & $\begin{array}{l}\text { - Large amount } \\
\text { interdendritic } \beta^{\prime}\end{array}$ & $\begin{array}{l}\text { - Reduced interdendritic } \beta^{\prime} \\
\text { Furnace cooled: } \\
\text { - G-phase, cubes, and } \\
\text { platelets } \\
\text { - } \beta^{\prime} \text { at G-phase platelet } \\
\text { sites }\end{array}$ & $\begin{array}{l}1300 \mathrm{~K} \text { aging: } \\
\beta^{\prime} \text { phase } \\
\text { - Complete dissolution of } \\
\text { G-phase }\end{array}$ & Not studied \\
\hline
\end{tabular}




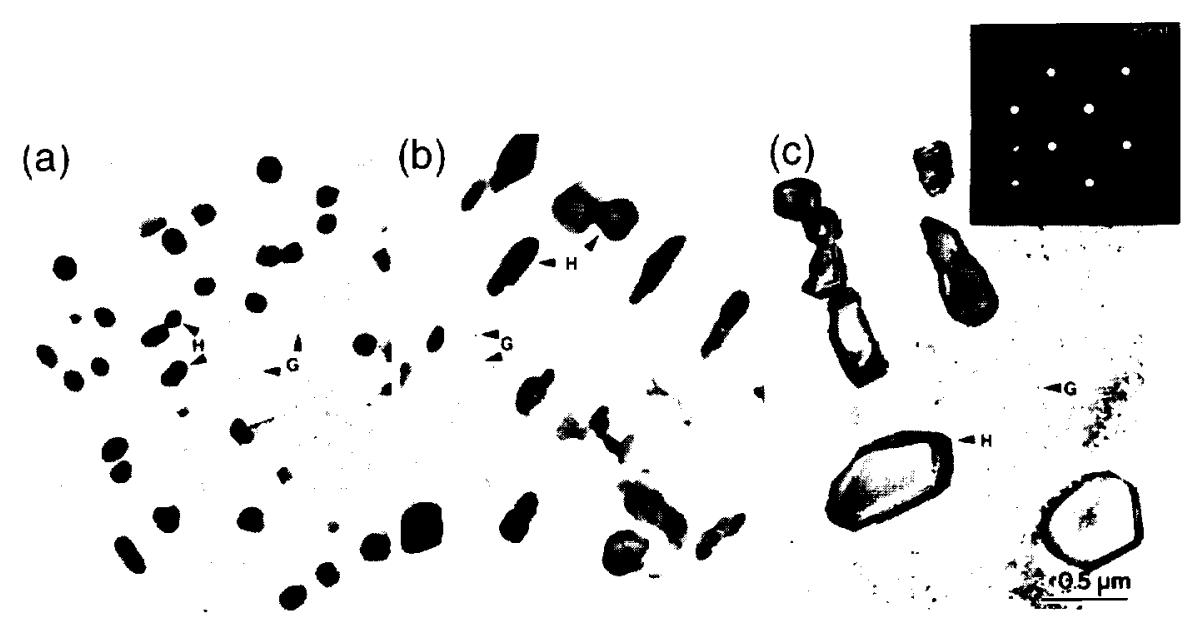

FIG. 14. TEM BF images from homogenized and air-cooled NiAl-1.0 at. \% Hf samples after aging for (a) 1 , (b) 100 , and (c) $500 \mathrm{~h}$ at $1300 \mathrm{~K}$. A $1001 \mid$ zone axis microdiffraction pattern of one of the large Heusler precipitates in (c) is included.

addition. For the Hf-containing alloys, the interdendritic phase was found to be the Heusler $\left(\mathrm{Ni}_{2} \mathrm{AlHf}\right)$ phase. This interdendritic Heusler phase has a solidus temperature close to $1618 \mathrm{~K}$ compared to $1880 \mathrm{~K}$ for the $\mathrm{NiAl}$ matrix, limiting the upper temperature at which the alloys could be homogenized without resulting in incipient melting. Therefore, factors controlling the dendritic spacing such as the directional solidification rate and thermal gradient, plus longer time or more complicated stepped heat treatments, could be explored to minimize the amount of interdendritic segregation and further optimize the distribution of the second phases observed in these systems.

In contrast to the interdendritic Heusler regions, the fine scale precipitation observed in these alloys after directional solidification or the homogenization treatment consisted predominantly of the G-phase

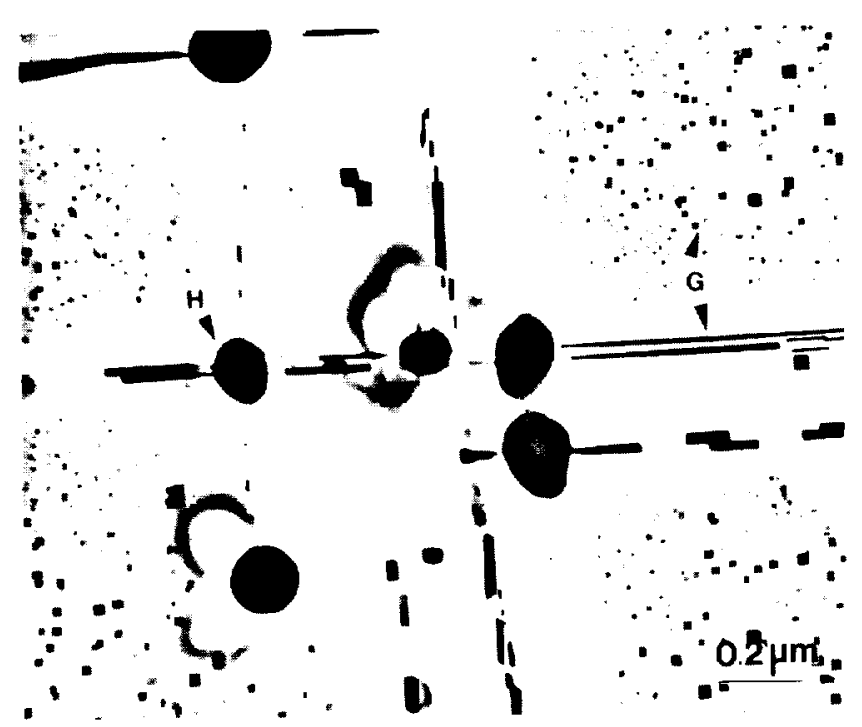

FlG. 15. TEM BF image showing a $\mathrm{NiAl}-1.0$ at. \% Hf alloy aged to $1300 \mathrm{~K}$ for $1 \mathrm{~h}$ after homogenization and furnace cooling. Heusler phase precipitates preferentially nucleated at G-phase platelet sites and $\mathrm{NiXSi}$ (where $\mathrm{X}=\mathrm{Hf}$ or $\mathrm{Zr}$ ) phase due to the presence of $\mathrm{Si}$ which was introduced into the alloys by reaction of the molten metal with the alumina-silicate shell molds. The G-phase precipitates are coherent, generally nucleating homogeneously except when they form as platelets, and are one of the first phases to form during cooling from the homogenization temperature. Its morphology is affected by cooling rate, resulting in platelets and cubes after slow cooling rates (furnace cooled $\sim 10 \mathrm{~K} / \mathrm{min}$ ), to finer, homogeneously distributed cuboidal particles during faster cooling rates (air cooled). The G-phase can be completely suppressed during very fast cooling rates such as water quenching from the homogenization temperature.

Some of the Hf-doped alloys also contained a low volume fraction of inhomogeneously distributed

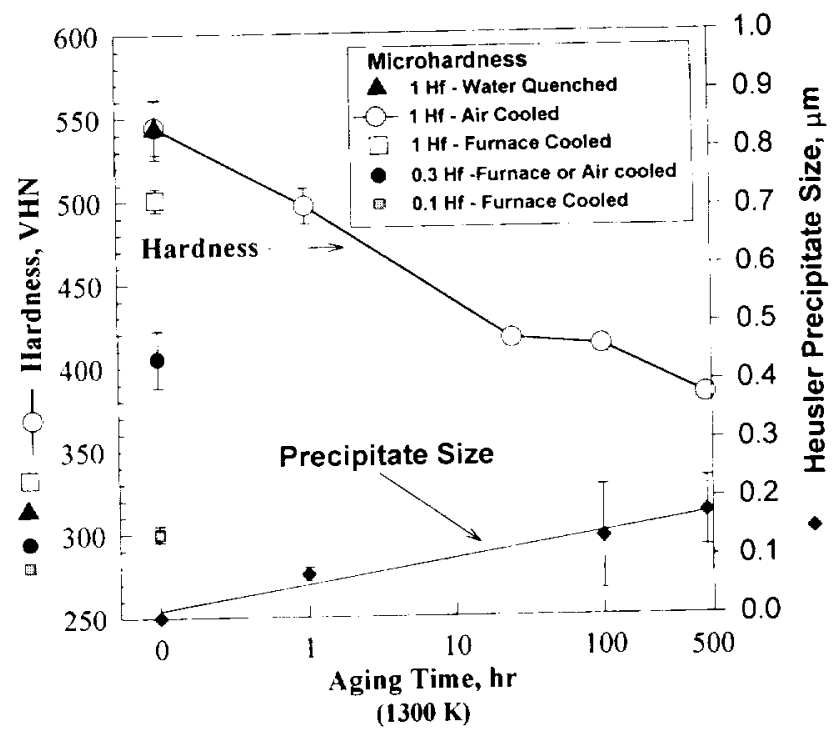

FIG. 16. Microhardness and Heusler precipitate size as a function of aging time measured in $\mathrm{NiAl}-\mathrm{Hf}$ alloys after a $1590 \mathrm{~K}$ heat treatment for $50 \mathrm{~h}$ followed by furnace, air cooting. or water quenching 

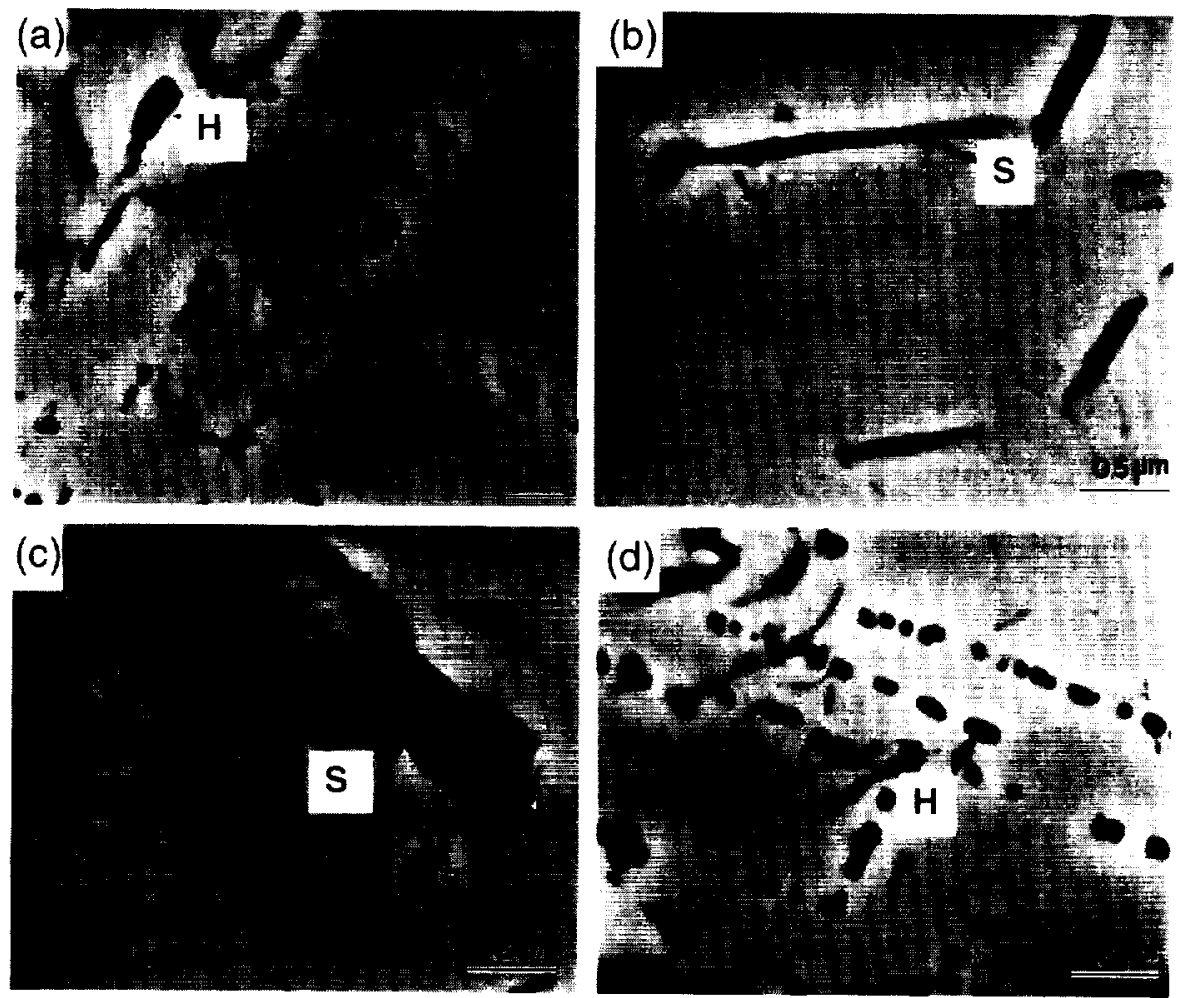

FIG. 17. TEM BF images showing (a) only Heusler precipitates in the NiAl-1.0 at. \% Hf alloy after an aging heat treatment of $1400 \mathrm{~K}$ for $20 \mathrm{~h}$ with a prior homogenization and furnace-cooled condition. (b) Only NiHfSi precipitates in the NiAl-0.3 $\mathrm{Hf}$ alloy aged at $1300 \mathrm{~K}$ for $168 \mathrm{~h}$. (c) Only NiZrSi precipitates in the NiAl-0.05 $\mathrm{Zr}$ alloy aged at $1300 \mathrm{~K}$ for $168 \mathrm{~h}$. (d) Only aligned $\beta^{\prime} \mathrm{Heusler}$ in the $\mathrm{NiAl}-1 \mathrm{Hf}-0.2 \mathrm{Zr}$ alloy aged at $1300 \mathrm{~K}$ for $1 \mathrm{~h}$ after homogenization and furnace cooling.

orthorhombic NiHfSi phase after homogenization. It has been shown ${ }^{24}$ that this precipitate has a $\{111\}_{\text {Nial }}$ habit plane with a rectangular morphology when viewed in its habit plane. The NiHfSi phase is larger than the G-phase cubes and closer in size though morphologically distinct from the G-platelets. Because it has a much larger misfit with the NiAl matrix, the presence of this phase has been attributed to an inhomogeneous nucleation mechanism. $^{24}$

Finally, the expected precipitate in these systems, the Heusler phase, was only marginally observed in the two alloys with the highest $\mathrm{Hf}$ and $\mathrm{Zr}$ levels after the homogenization treatment. Consequently, cooling from the homogenization temperature tended to favor the nucleation of G-phase with its low misfit or the NiXSi phase probably due to its unique inhomogeneous nucleation mechanism. ${ }^{24}$ Though the aging data in Table IV are far from complete, it appears that the Heusler phase was more common after aging at intermediate temperatures, indicating that in some, but not all the alloys it was the thermally stable phase. For example, both the $\mathrm{NiAl}-1 \mathrm{Hf}$ and $\mathrm{NiAl}-1 \mathrm{Hf}-0.2 \mathrm{Zr}$ alloys were partially or completely composed of Heusler precipitates at the expense of the original G-phase after long-term aging treatments. If G-phase platelets are present, nucleation of Heusler precipitates preferentially occurs at this site, whereas, if only a fine and uniform distribution of G-phase cubes is present (e.g., air-cooled condition), then the Heusler phase also precipitates homogeneously. The dissolution of the G-phase precipitates and the formation and growth of the Heusler precipitates is accompanied by a reduction in microhardness, and also was observed to reduce creep life. ${ }^{15,27}$ In contrast, the $\mathrm{NiAl}-0.05 \mathrm{Zr}$ and the $\mathrm{NiAl}-0.3 \mathrm{Hf}$ alloys consisted entirely of the NiHfSi phase after long-term aging.

In light of the data shown in Table IV, which is consistent with observations in a companion study on similar alloys, ${ }^{28}$ these observations can be explained in terms of the reactive element to silicon ratio. In those alloys where Heusler was stable after aging (see Table IV), the reactive element to silicon ratio was high (on the order of 3 to 7), whereas the NiXSi phase was stable in alloys which had a low reactive element to silicon ratio (on the order of 0.3 to 1.8 ). It is likely that at intermediate values of this ratio, a stable three-phase alloy composed of $\mathrm{NiAl}$, Heusler, and silicide phase would likely exist. However, additional work will be needed to fully understand the effect of small chemical composition differences, especially $\mathrm{Si}$, on the stability of the microstructure in these alloys. 


\section{v. CONCLUSIONS}

The following conclusions were drawn from the preceding results:

(1) Three distinct phases formed in $\mathrm{NiAl}$ single crystal alloys when $\mathrm{Hf}, \mathrm{Zr}$, and $\mathrm{Si}$ are present: G-phase, Heusler, and NiXSi. Higher levels of ternary additions resulted in coarse regions of interdendritic segregation which were difficult to eliminate by short time homogenization heat treatments. The presence of $\mathrm{Si}$ in these systems changed the expected phase formation from Heusler to Si-containing precipitates.

(2) G-phase $\left(\mathrm{Ni}_{16} \mathrm{X}_{6} \mathrm{Si}_{7}\right)$ precipitation was common in all three systems. After homogenization, the G-phase morphology could be changed by varying the cooling rates and the G-phase precipitation could be completely suppressed by water quenching.

(3) For the $\mathrm{NiAl}-1 \mathrm{Hf}$ and $\mathrm{NiAl}-1 \mathrm{Hf}-0.2 \mathrm{Zr}$ alloys studied, the stable phase after aging was the Heusler phase. Heusler precipitates coarsened at the expense of the G-phase. However, in the NiAl alloys with low levels of $\mathrm{Hf}$ or $\mathrm{Zr}$, long-term aging resulted in the formation of the orthorhombic NiXSi phase.

(4) The reactive element to silicon ratio appears to determine the stable phase after long-term aging.

(5) These results show the potential for controlling the microstructure of these alloys by thermal treatments. The resultant mechanical properties as a function of precipitate distribution is an area of future study.

\section{ACKNOWLEDGMENTS}

The authors would like to thank Professor B. Oliver (U. of Tennessee) for supplying the NiAl-1Hf-0.2Zr ingot. Helpful discussions with Dr. Scott Walston (GEAE) are greatly appreciated.

\section{REFERENCES}

1. C. A. Barret, Oxidation of Metals 30, 361 (1988).

2. J. Doychak, J.L. Smialek, and T. E. Mitchell, Metall. Trans. A 20. 499 (1989).

3. K. Vedula, V. Pathare, I. Aslandis, and R. H. Titran, in HighTemperature Ordered Intermetallic Alloys, edited by C. C. Koch, C. T. Liu, and N.S. Stoloff (Mater. Res. Soc. Symp. Proc. 39 Pittsburgh, PA, 1985), pp. 411-421.

4. J. D. Whittenberger, M. V. Nathal, S. V. Raj, and V.M. Pathare, Mater. Lett. 11, 267 (1991).

5. J. D. Whittenberger and R. D. Noebe, Metall. Trans. (1995, in press).

6. R. Darolia, D.F. Lahrman, R. D. Field, J. R. Dobbs, K. M. Chang, E.H. Goldman, and D.G. Konitzer, in Ordered Intermetallics-Physical Metallurgy and Mechanical Behavior. edited by C.T. Liu, R.W. Cahn, and G. Sauthoff (Kluwer Academic Publishers, The Netherlands, 1992), pp. 679-698.

7. R. Darolia, J. Metals 43 (3), 44 (1991).
8. R. Darolia. in Structural Intermetallics, edited by R. Darolia, J. J Lewansdowski, C. T. Liu, P. L. Martin, D. B. Miracle, and M. V. Nathal (The Minerals, Metals \& Materials Society, Pennington. NJ, 1993), pp. 495-504.

9. R. D. Reviere, B. F. Oliver, and D. D. Bruns, Materials \& Manufacturing Processes 4 (1). 103 (1989).

10. E. H. Goldman, in High Temperature Ordered Intermetallic Allows $V$, edited by I. Baker, R. Darolia, J. D. Whitteneberger, and M. H. Yoo, (Mater. Res. Soc. Symp. Proc. 288. Pittsburgh, PA. 1993). p. 83.

11. J. A. Oti and K.O. Yu, in Structural Intermetallics, edited by R. Darolia, J. J. Lewansdowski, C. T. Liu. P. L. Martin, D. B. Miracle, and M.V. Nathal (The Minerals, Metals \& Materials Society, Pennington, NJ, 1993), pp. 505-511.

12. K. O. Yu, J. A. Oti, and W. S. Walston, J. Metals 45 (5), 49 (1993).

13. I. E. Locei and R. D. Noebe, in Proceedings of the $47 \mathrm{th} \mathrm{An}$ nual Meeting of the Electron Microscopy Society of America (San Francisco Press, Inc., 1989), pp. 308-309.

14. I. E. Locci, R. D. Noebe, R. R. Bowman, R. V. Miner, M. V Nathal, and R. Darolia, in High-Temperature Ordered Intermetallic Alloys $I V$, edited by L. A. Johnson. D. P. Pope, and J.O. Stiegler (Mater. Res. Soc. Symp. Proc. 213, Pittsburgh. PA. 1991), pp. $1013-1018$.

15. I. E. Locci, R. Dickerson, R. R. Bowman, J.D. Whittenberger, M. V. Nathal, and R. Darolia. in High-Temperature Ordered Intermetallic Alloys $V$, edited by I. Baker, R. Darolia, J.D. Whittenberger, and M. H. Yoo (Mater. Res. Soc. Symp. Proc. 288. Pittsburgh, PA 1993), pp. 685-690.

16. S. W. Walston and R. Darolia, ibid. pp. 237-242.

17. P. Nash and Y. Y. Pan. J. Phase Equilibria 12 (1). 105 (1991).

18. K. J. Lee and P. Nash, J. Phase Equilibria 12 (1). 94 (1991).

19. M. Takeyama, C. T. Liu, and C. J. Sparks, Jr., in Proc Int. Symp. on Intermetallics Compounds (JIMIS-6), Sendai, Japan, edited by Osamu Izumi (1991), pp. 871-875.

20. P. Nash, in High-temperature Ordered Intermetallic Alloys, edited by C. C. Koch, C. T. Liu, and N.S. Stoloff (Mater. Res. Soc. Symp. Proc. 39, Pittsburgh, PA, 1985), pp. 423-427.

21. Unpublished results, NASA-Lewis Research Center and GEAE.

22. E. I. Gladyshevskii, P. I. Kripyakevich, Yu. B. Kuz'ma, and M. Yu. Teslyuk, Kristallografiya 6 (5), 769 (1961).

23. F. X. Spiegel, D. Bardos, and P. A. Beck. Trans. Metall Soc., AIME, 227, 575 (1963)

24. A. Garg, R. D. Noebe, and R. Darolia, Acta Mater. 44 (7), 2809 (1996).

25. Pearsons Handbook of Crystallographic Data for Intermetallic Phases, edited by P. Villars and L.D. Calvert, 2nd ed. (ASM INTERNATIONAL, Materials Park, OH), Vol. 3, p. 3895.

26. Pearsons Handbook of Crystallographic Data for Intermetallic Phases, edited by P. Villars and L.D. Calvert, 2nd ed. (ASM INTERNATIONAL, Materials Park, OH), Vol. 4, p. 4692.

27. I. E. Locci, J. D. Whittenberger, R. M. Dickerson, R. D. Noebe, M. V. Nathal, and R. Darolia, "High Temperature Mechanical Properties of NiAl Single Crystals with additions of $\mathrm{Hf}$ and $\mathrm{Zr}$ " (unpublished).

28. A. Garg, R. D. Noebe, and R. Darolia, NASA Conference Publication 10178. 1995, paper 28.

29. E. I. Gladyshevskii, V.Y. Markiv, and Y.B. Kuzma, Dopov. Akad. Nauk. Ukr. RSR 4, 481 (1962).

30. E. I. Gladyshevskii and L. K. Borusevich. Russ. J. Inorg. Chem. $8(8), 997$ (1963). 
- 